\title{
Poverty, Inequality and Ethnic Minorities in Vietnam
}

Katsushi Imai

University of Manchester, UK

Raghav Gaiha

Faculty of Management Studies,

University of Delhi, India

December 2007

katsushi.imai@manchester.ac.uk

Department of Economics

School of Social Sciences

University of Manchester

Arthur Lewis Building

Oxford Road

Manchester M13 9PL

\section{BWPI Working Paper 10}




\begin{abstract}
The present study examines how and why ethnic minorities are poorer than ethnic majorities in Vietnam using the VHLSS data for 2002 and 2004. First, the analysis confirms that households belonging to the ethnic minority groups are not only poorer but also more vulnerable to various shocks than those in the ethnic majority groups, namely the Kinh and the Chinese. Second, household composition (e.g. dependency burden), education, land holding, and location are important determinants of expenditure and poverty, whilst there is some diversity among different ethnic groups. Finally, the decomposition analyses reveal that the ethnic minorities are poorer not necessarily because they have more disadvantaged household characteristics (e.g. educational attainment or location), but, more importantly, because the returns to the characteristics are much lower for ethnic minorities than for majorities. Government policies to reduce structural differences between ethnic majorities and minorities are imperative to address the disparities in returns to endowments between them.
\end{abstract}

Keywords: Vietnam, ethnic minority, poverty, inequality, decomposition

This paper is based on the project the authors carried out for the Asia and Pacific Division of the IFAD, under the overall supervision of Dr. Ganesh Thapa, Regional Economist for Asia and the Pacific region. The first author acknowledges the support from the University of Manchester and from Doshisha University to carry out this research. However, only the authors are responsible for any errors. 


\section{Introduction}

Vietnam is a multi-ethnic country with 54 ethnic groups, each has its own language, lifestyle and cultural heritage. The most dominant group is called "Viet" or "Kinh", which accounts for $86 \%$ of the population of about 84 million and is concentrated in inland deltas and coastal areas. They have political and economic power and are generally richer than minority groups, with easy access to infrastructure, health services, and education. "Hoa" or Chinese is another relatively rich group that also inhabits mainly in inland deltas and coastal areas. In the present study, we define 'ethnic majorities' as the Kinh and the Chinese, and 'ethnic minorities' as the ethnic groups other than these, following van de Walle and Gunewardena (2001). Many studies have shown that ethnic minorities are concentrated in upland and mountain areas where access to infrastructure or health and educational facilities is limited and they are much poorer than the ethnic majorities (e.g. van de Walle and Gunewardena, 2001; ADB 2002; World Bank, 2004; Gaiha and Thapa, 2006; Imai, Gaiha and Kang, 2007). Indeed, the issue of poverty in Vietnam cannot be addressed without analysing the poverty of ethnic minorities, as their poverty headcount ratio was $64.3 \%$ in 2002 , almost three times larger than that of ethnic majorities (22.3\%) (see Table 3). The share of ethnic minorities among the poor in the whole nation rose from $20 \%$ in 1993 to $30 \%$ in 2002 due to poverty reduction in ethnic majority groups and poverty stagnation in the minority groups (World Bank, 2004). While the national poverty rate fell from $58.1 \%$ in 1993 to $37.4 \%$ in 1998 and to $28.9 \%$ in $2002^{1}$, and Vietnam had already achieved the Millennium Development Goal of halving income poverty by 1998, poverty reduction of the ethnic minority groups is still an important policy concern.

Why disparities in well-being and in poverty rates persist between the ethnic majorities and minorities is far from obvious. It may be asked, for example, whether ethnic minorities are poorer simply because they are located in remote areas or because they do not have enough human or physical capitals, such as education or land, or because of any structural constraints (e.g. social exclusion)? To address this question, van de Walle and Gunewardena (2001) applied the Oaxaca-Blinder decomposition of wage inequality into two components: one due to differences in socio-economic characteristics and the other due to structural factors or differences in the returns to these characteristics (Oaxaca, 1973; Blinder, 1973). Their analysis was confined to expenditure of households mainly in Northern Vietnam using the Viet Nam Living Standards Measurement Surveys (VNLSS) in 1992-1993. They show that, without commune fixed effects, about one- half of the expenditure inequality between the ethnic

\footnotetext{
${ }^{1}$ Poverty rates used here are based on the international poverty line which was devised by the Vietnamese General Statistics Office (GSO) to reflect food expenditure for an intake of 2100 calories a day and corresponding non-food expenditure. The basket of food and non-food items is determined by the consumption patterns of the third quintile of households in terms of per capita expenditure. The poverty lines were VND 1.16 million per person per year in 1993, VND 1.79 million in 1998 and VND 1.92 million in 2002. In the present study, we use the same international poverty line and adjust it for 2004, based on the annual CPI. We have not used the poverty lines developed by the Ministry of Labour, Invalids and Social Affairs (MOLISA), which reflect the regional disparity in rice consumption.
} 
majorities and minorities is explained by the characteristic component and another half by the structural component, whilst most of the expenditure inequality comes from the structural factor once commune fixed effects are taken into account for selected communes where both majority and minority groups are found ${ }^{2}$. We extend van de Walle and Gunewardena (2001) using more recent and larger household data sets, namely, Vietnam Household Living Standards Survey (VHLSS) for 2002 and 2004. First, given the possible diversity among the ethnic minority groups, we will estimate the expenditure function separately for each ethnic group. Second, we will use some recent decomposition methods applied to analyse persistent poverty among the scheduled caste and tribes in India (e.g. Borooah, 2005; Kijima, 2006; Gang, Sen, and Yun, 2006; Gaiha et al., 2007). For example, we will carry out the decomposition analysis not only for expenditure inequality but also for differences in poverty levels of ethnic majorities and minorities. Moreover, we will disaggregate the decomposition of expenditure inequality and poverty differences into the effects of each explanatory variable. Our analysis is thus designed to throw additional light on persistent ethnic poverty and inequality.

The rest of the paper is organised as follows. In the next section, we will first review the data, and then comment on the estimates of poverty and vulnerability, and their correlates. Section 3 discusses the methodology used to analyse poverty of ethnic minorities, including the decomposition methods. Detailed econometric results are discussed in Section 4. The final section offers some concluding remarks.

\section{Data and Descriptive Statistics}

\subsection{Data $^{3}$}

Most of the poverty assessments in Vietnam are based on Vietnam Living Standards Surveys (VLSS) in 1992/3 and 1997/8, which covered 4,800 and 6,000 households, respectively. Of these, about 4,300 households constitute a panel data set. The surveys were designed to collect detailed data on households, communities, and market prices. While VLSS were widely recognised as high quality, they required additional surveys, called Multi-Purpose Household Surveys (MPHS), to provide estimates at provincial level due to the relatively small sample size of VLSS. In 2002, VLSS and MPHS were merged into Vietnam Household Living Standards Survey (VHLSS) to cover the larger sample of households with some simplification of the questionnaires to minimize measurement errors. VHLSS is planned to be carried out every two years until 2010.

VHLSS is supposed to have two modules: the core module includes topics which are important

\footnotetext{
${ }^{2}$ They selected those communes to avoid the problem of missing regressors. We do not take this approach as we can find the same set of regressors in our larger data (i.e. VHLSS in 2002 and 2004) for communes where either an ethnic majority group or a minority group is found

${ }^{3}$ This sub-section draws upon Imai, Gaiha and Kang (2007).
} 
and change rapidly over time, while the rotated module focuses on those that change less often. However, VHLSS in 2002 contains only the core module. It covers a wide range of data, including household composition and characteristics (e.g. education and health), expenditures on food, non-food items, health and education, income by source (e.g. wage and salary, farm or non-farm production), employment and labour force participation, housing, ownership of assets and durable goods, local infrastructure and commune characteristics. The sample size of VHLSS 2002 is 75,000 households, of which 30,000 households were interviewed with all topics, and 45,000 with all topics except expenditure. Only the former is used for the present study, as our focus is on income/expenditure poverty. Because of missing observations for some variables, the final sample size is 28,806 .

VHLSS in 2004 consists of the core module virtually identical to the 2002 survey, and the rotated module on agricultural activities and non-agricultural household business, and borrowing and lending activities. The total number of households is 45,000 , of which 9,000 households were interviewed with all topics, and 36,000 households with all topics except expenditure. We use only 9000 households interviewed on all topics. Due to missing observations, the final size is 6,473 . Given the larger sample size of the survey data in 2002 , we will mainly use the data in 2002 and supplement them by the data in 2004 .

\subsection{Poverty among Ethnic Minorities}

This sub-section focuses on socio-economic characteristics of ethnic majorities and minorities as well as their sub-categories. Table 1 shows the geographical location of ethnic groups based on VHLSS data for 2004. Our comments are brief and selective.

First, $57 \%$ of the ethnic majority groups, the Kinh and the Chinese, live in Inland Delta, while the corresponding figure for the ethnic minority groups is just $10 \%$. The ethnic minorities living in Inland Delta consists mainly of the Khmer, which is known as the Khmer Krom, who inhabited the delta of the Mekong long before the arrival of the Vietnamese. The ethnic majorities also live in low and high mountains (29\%), coastal area ( $8 \%)$, and hills $(7 \%)$. Few ethnic minority groups live in coastal area and hills- $62 \%$ of them inhabit high mountains and $27 \%$ are in low mountains. There are a few ethnic groups located mainly in low mountains, such as the Muong, the Sandiu and the Stieng, but most of the minority groups are based primarily in high mountain areas.

Table 2 compares measures of disadvantage of ethnic majorities and minorities. It is confirmed that (i) a majority of the ethnic minority groups live in remote areas (defined subjectively by the survey); (ii) about $90 \%$ of the ethnic minority people live in rural areas; (iii) the ethnic majority groups do not have easy access to the market, or medical care. While the degree of disadvantage varies across different ethnic minority groups, all the minority groups are geographically more disadvantaged than the majorities in terms of market access or health services. 
Table 1 - Geographical Location of Ethnic Groups in Vietnam in 2002 (\%)

\begin{tabular}{|c|c|c|c|c|c|c|c|c|c|c|c|}
\hline & Total & & Majority & Kinh & Chinese & & Minority & Tay & Thai & Khmer & Muong \\
\hline \multicolumn{12}{|c|}{ Geographical Location } \\
\hline Coastal & 7.8 & & 8.9 & 8.8 & 17.4 & & 0.8 & 0.0 & 0.0 & 11.5 & 0.0 \\
\hline Inland Delta & 56.5 & & 64.0 & 63.9 & 52.2 & & 10.1 & 0.5 & 1.0 & 75.0 & 0.0 \\
\hline Hills & 7.0 & & 8.0 & 8.0 & 5.3 & & 1.0 & 0.5 & 0.0 & 0.0 & 0.0 \\
\hline Low Mountains & 15.2 & & 13.4 & 13.4 & 15.5 & & 26.5 & 32.1 & 22.5 & 13.5 & 64.4 \\
\hline High Mountains & 13.4 & & 5.7 & 5.8 & 9.7 & & 61.6 & 67.0 & 76.5 & 0.0 & 35.6 \\
\hline Total & 100.0 & & 100.0 & 100.0 & 100.0 & & 100.0 & 100.0 & 100.0 & 100.0 & 100.0 \\
\hline \multirow[t]{2}{*}{ No. of Observations } & 29530 & & 24560 & 25108 & 212 & & 4074 & 1045 & 1862 & 260 & 450 \\
\hline & Dao & Ngai & Ede & Coho & Bana & Sandiu & Sedang & Stieng & Gietrieg & Stingmun & Other \\
\hline \multicolumn{12}{|c|}{ Geographical Location } \\
\hline Coastal & 0.0 & 0.0 & 0.0 & 0.0 & 0.0 & 9.3 & 0.0 & 0.0 & 0.0 & 0.0 & 0.2 \\
\hline Inland Delta & 0.0 & 0.8 & 1.8 & 0.9 & 0.0 & 0.0 & 0.0 & 0.0 & 0.0 & 0.0 & 3.8 \\
\hline Hills & 0.0 & 0.0 & 0.9 & 0.0 & 4.8 & 3.5 & 1.4 & 0.0 & 0.0 & 0.0 & 0.5 \\
\hline Low Mountains & 14.6 & 24.8 & 27.5 & 1.9 & 5.8 & 75.6 & 2.8 & 85.7 & 0.0 & 0.0 & 16.4 \\
\hline High Mountains & 85.4 & 74.4 & 69.7 & 97.2 & 89.4 & 11.6 & 95.8 & 14.3 & 100.0 & 100.0 & 79.1 \\
\hline Total & 100.0 & 100.0 & 100.0 & 100.0 & 100.0 & 100.0 & 100.0 & 100.0 & 100.0 & 100.0 & 100.0 \\
\hline No. of Observations & 138 & 126 & 109 & 108 & 104 & 87 & 77 & 42 & 29 & 28 & 1640 \\
\hline
\end{tabular}

* The highest percentage for each category is shown in bold. 
Table 2 - Measures of Disadvantage by Ethnic Group in Vietnam in 2002

\begin{tabular}{|c|c|c|c|c|c|c|c|c|c|c|}
\hline $\begin{array}{l}\text { Remoteness/ } \\
\text { Infrastructure }\end{array}$ & Total & Majority & Kinh & Chinese & Minority & Tay & Thai & Khmer & Muong & Nung \\
\hline $\begin{array}{l}\text { Whether a household is } \\
\text { in a remote area }\end{array}$ & 0.17 & 0.11 & 0.11 & 0.24 & 0.58 & 0.56 & 0.56 & 0.54 & 0.50 & 0.83 \\
\hline $\begin{array}{l}\text { Whether a household is } \\
\text { in a rural area }\end{array}$ & 0.77 & 0.74 & 0.74 & 0.45 & 0.92 & 0.92 & 0.90 & 0.98 & 1.00 & 0.98 \\
\hline $\begin{array}{l}\text { Whether a household has } \\
\text { access to the daymarket }\end{array}$ & 0.33 & 0.35 & 0.35 & 0.17 & 0.18 & 0.11 & 0.16 & 0.38 & 0.18 & 0.28 \\
\hline $\begin{array}{l}\text { The distance from } \\
\text { the daymarket }\end{array}$ & 2.76 & 1.50 & 1.50 & 1.45 & 10.34 & 11.48 & 10.55 & 2.01 & 6.85 & 12.33 \\
\hline $\begin{array}{l}\text { Whether a household } \\
\text { has access to the } \\
\text { daymarket }\end{array}$ & 0.94 & 0.98 & 0.98 & 0.97 & 0.64 & 0.68 & 0.38 & 0.98 & 0.59 & 0.65 \\
\hline No. of Observations & 29530 & 24560 & 25108 & 212 & 4074 & 1045 & 1862 & 260 & 450 & 450 \\
\hline
\end{tabular}

\begin{tabular}{|c|c|c|c|c|c|c|c|c|c|c|c|}
\hline $\begin{array}{l}\text { Remoteness/ } \\
\text { Infrastructure }\end{array}$ & Dao & Ngai & Ede & Coho & Bana & Sandiu & Sedang & Stieng & Gietrieg & Stingmun & Other \\
\hline $\begin{array}{l}\text { Whether a household is } \\
\text { in a remote area }\end{array}$ & 0.88 & 0.44 & 0.30 & 0.64 & 0.78 & 0.13 & 0.72 & 0.83 & 0.17 & 1.00 & 0.76 \\
\hline $\begin{array}{l}\text { Whether a household is } \\
\text { in a rural area }\end{array}$ & 0.98 & 0.91 & 0.93 & 0.85 & 0.99 & 0.78 & 0.94 & 0.98 & 1.00 & 1.00 & 0.98 \\
\hline $\begin{array}{l}\text { Whether a household has } \\
\text { access to the daymarket }\end{array}$ & 0.07 & 0.17 & 0.65 & 0.01 & 0.02 & 0.02 & 0.01 & 0.12 & 0.00 & 0.00 & 0.20 \\
\hline
\end{tabular}




\begin{tabular}{|c|c|c|c|c|c|c|c|c|c|c|c|}
\hline $\begin{array}{l}\text { Remoteness/ } \\
\text { Infrastructure }\end{array}$ & Dao & Ngai & Ede & Coho & Bana & Sandiu & Sedang & Stieng & Gietrieg & Stingmun & Other \\
\hline $\begin{array}{l}\text { The distance from } \\
\text { the daymarket }\end{array}$ & 23.15 & 3.98 & 1.72 & 10.57 & 20.61 & 8.28 & 16.35 & 7.24 & 18.53 & 13.57 & 13.25 \\
\hline $\begin{array}{l}\text { Whether a household } \\
\text { has access to the } \\
\text { daymarket }\end{array}$ & 0.45 & 0.95 & 0.98 & 0.77 & 0.48 & 0.81 & 0.44 & 1.00 & 1.00 & 0.00 & 0.53 \\
\hline $\begin{array}{l}\text { Whether a household } \\
\text { has access to Hospital }\end{array}$ & 0.08 & 0.03 & 0.27 & 0.14 & 0.02 & 0.36 & 0.04 & 0.07 & 0.00 & 0.18 & 0.10 \\
\hline No. of Observations & 138 & 126 & 109 & 108 & 104 & 87 & 77 & 42 & 29 & 28 & 1640 \\
\hline
\end{tabular}


Table 3 summarises poverty and vulnerability measures for ethnic majority and minority groups. Poverty head count ratio is based on the national poverty line, and two alternative cases where $80 \%$ and $120 \%$ of the poverty line are considered to check the sensitivity of the results. Vulnerability measure is defined as the probability of falling into poverty in the next period, following Chaudhuri, Jalan, and Suryahadi (2002). ${ }^{4}$ The results for VHLSS data for 2004 are given in Table $4 .{ }^{5}$ Only key findings from these tables are summarized below.

First, the poverty headcount ratio of the ethnic majority groups remained much lower than that of ethnic minority groups in 2002 and 2004 (22.3\% in 2002 and $20.2 \%$ in 2004 for the majority ${ }^{6}$, and $64.3 \%$ in 2002 and $62.1 \%$ in 2004 for the minority).

Second, the poverty head count ratio varies among ethnic minority groups, ranging from $28.1 \%$ for the Khmer, $50 \%$ for the Nung, to $95.2 \%$ for the Bana. This suggests that policy efforts are necessary to provide more intensive support for the poorest and the most disadvantaged ethnic groups. Third, this pattern is largely unchanged if $80 \%$ or $120 \%$ of the poverty line is employed. Finally, the difference in 'vulnerability' of ethnic majority groups and minority groups is much higher ( $7.3 \%$ versus $62.1 \%$ ) than the difference in poverty ( $22.3 \%$ versus $64.3 \%)$. This implies that ethnic minorities are much more vulnerable to various shocks (e.g. sudden weather changes or illness of household members) than the majority groups. ${ }^{7}$ This implies that government policies designed to augment household incomes alone are not likely to be effective in reducing poverty among ethnic minorities in the long run. More attention needs to be given to social safety nets or insurance to protect the vulnerable ethnic minorities from shocks.

Table 5 compares average household characteristics of the ethnic majority and minority groups in 2002. The findings are briefly summarised below. First, the average age of household head is 5 years higher for the majority groups (48.2 years old) than for the minority groups (43.2). However, the Khmer is an exception as the average age of the head is high (50.3). Second, the average household size of the minority groups is larger (5.35) than that of the majority groups (4.34). This reflects the heavier dependency burden among the ethnic minority groups. $7.8 \%$ of the households of ethnic majority groups have members who completed higher education, while the corresponding figure of ethnic minorities is only $2.5 \%$. The share of households with the educational level at upper secondary school is $18.3 \%$ for the former and $8.8 \%$ of the latter.

\footnotetext{
${ }^{4}$ See Appendix 1 for computational details of the vulnerability measures.

${ }^{5}$ As the sample size differs in the VHLSS for 2002 and 2004, some caution is required in comparisons of the results.

${ }^{6}$ A further disaggregation shows that poverty head- count ratio of the Kinh decreased from $23.2 \%$ to $20.2 \%$, while that of the Chinese increased from $14.6 \%$ to $20.2 \%$. However, the latter should be interpreted cautiously because of the small sample size of Chinese households (212 in 2002 and 63 in 2004).

${ }^{7}$ See Imai, Gaiha, and Kang (2007) for more details.
} 
Third, ethnic minority groups have larger areas of land than do ethnic majorities without any exception. Disaggregation of the total area of land into subcategories shows that ethnic minorities hold larger areas for all the categories except for aquacultural water (i.e. for agricultural land, sylvicultural land and unused land). Fourth, despite some variation across different ethnic minority groups, they have generally similar characteristics (e.g. large household size, low educational attainments). Recent anthropological and other related studies focusing on the disparities among different ethnic groups or different regions are generally consistent with the above findings. ${ }^{8}$ For example, McElwee (2006),focusing on the relationship between minority groups and the Kinh in the Annamite uplands, reports that social and economic inequality worsened due to unequal access to markets, government services and political representation. Scott and Chuyen (2004), on the other hand, demonstrate that regional disparities stemmed from some regions' limited access to resources, information, and social infrastructure for entrepreneurial and other development activities. In an important variation, Fforde (1998) draws attention to differences in capacities to work in a process of adjustment of structure of household earnings to changing circumstances. From a broader methodological perspective, he questions the homogeneity assumption that underlies some recent contributions (Fforde, 2005). If, for example, attitudes towards risks and insurance vary in different groups-as illustrated by Fforde (1998)- it is necessary to go beyond physical and human capital endowments and market failures to reduce vulnerability. Specifically, more careful attention must be given to correcting "community failures" (e.g. in protecting the old, and orphans). We will address some of these issues using econometric techniques.

\footnotetext{
${ }^{8}$ This review draws upon Imai, Gaiha, and Kang (2007).
} 
Table 3 - Poverty and Vulnerability by Ethnic Group in Vietnam in 2002

\begin{tabular}{|c|c|c|c|c|c|c|c|c|c|c|c|c|}
\hline & Total & & Majority & Kinh & Chinese & & Minority & Tay & Thai & Khmer & Muong & Nung \\
\hline Real Consumption per capita & 3480 & & 3727 & 3699 & 5260 & & 1939 & 2180 & 2180 & 2750 & 1735 & 2200 \\
\hline $\begin{array}{l}\text { Poverty Headcount } 80 \\
\text { (based on } 80 \% \text { of the poverty line) }\end{array}$ & 0.155 & & 0.106 & 0.113 & 0.071 & & 0.461 & 0.389 & 0.437 & 0.135 & 0.542 & 0.330 \\
\hline $\begin{array}{l}\text { Poverty Headcount } 100 \\
\text { (based on } 100 \% \text { of the poverty } \\
\text { line) }\end{array}$ & 0.281 & & 0.223 & 0.232 & 0.146 & & 0.643 & 0.586 & 0.622 & 0.281 & 0.711 & 0.500 \\
\hline $\begin{array}{l}\text { Poverty Headcount } 120 \\
\text { (based on } 120 \% \text { of the poverty } \\
\text { line) }\end{array}$ & 0.406 & & 0.349 & 0.358 & 0.212 & & 0.761 & 0.710 & 0.751 & 0.496 & 0.807 & 0.683 \\
\hline $\begin{array}{l}\text { Vulnerability Measure } 80 \\
\text { (based on } 80 \% \text { of the poverty line) }\end{array}$ & 0.057 & & 0.010 & 0.005 & 0.033 & & 0.351 & 0.301 & 0.449 & 0.027 & 0.490 & 0.193 \\
\hline $\begin{array}{l}\text { Vulnerability Measure } 100 \\
\text { (based on } 100 \% \text { of the poverty } \\
\text { line) }\end{array}$ & 0.149 & & 0.073 & 0.068 & 0.123 & & 0.621 & 0.637 & 0.745 & 0.160 & 0.809 & 0.517 \\
\hline $\begin{array}{l}\text { Vulnerability Measure } 120 \\
\text { (based on } 120 \% \text { of the poverty } \\
\text { line) }\end{array}$ & 0.339 & & 0.268 & 0.266 & 0.250 & & 0.782 & 0.799 & 0.848 & 0.389 & 0.927 & 0.756 \\
\hline No. of Observations & 29530 & & 24560 & 25108 & 212 & & 4074 & 1045 & 1862 & 260 & 450 & 450 \\
\hline & Dao & Ngai & Ede & Coho & Bana & Sandiu & Sedang & Stieng & Gietrieg & Stingmun & Other & \\
\hline Real Consumption per capita & 1815 & 1348 & 1618 & 1580 & 1074 & 2861 & 1526 & 1513 & 1644 & 1637 & 2686 & \\
\hline Poverty Headcount 80 & 0.478 & 0.730 & 0.486 & 0.556 & 0.827 & 0.241 & 0.519 & 0.571 & 0.414 & 0.286 & 0.305 & \\
\hline (based on $80 \%$ of the poverty line) & Dao & Ngai & Ede & Coho & Bana & Sandiu & Sedang & Stieng & Gietrieg & Stingmun & Other & \\
\hline
\end{tabular}




\begin{tabular}{|c|c|c|c|c|c|c|c|c|c|c|c|}
\hline $\begin{array}{l}\text { Poverty Headcount } 100 \\
\text { (based on } 100 \% \text { of the poverty } \\
\text { line) }\end{array}$ & 0.812 & 0.825 & 0.688 & 0.750 & 0.952 & 0.379 & 0.740 & 0.738 & 0.621 & 0.750 & 0.446 \\
\hline $\begin{array}{l}\text { Poverty Headcount } 120 \\
\text { (based on } 120 \% \text { of the poverty } \\
\text { line) }\end{array}$ & 0.862 & 0.905 & 0.817 & 0.815 & 0.971 & 0.471 & 0.818 & 0.857 & 0.862 & 0.929 & 0.567 \\
\hline $\begin{array}{l}\text { Vulnerability Measure } 80 \\
\text { (based on } 80 \% \text { of the poverty line) }\end{array}$ & 0.440 & 0.479 & 0.099 & 0.476 & 0.712 & 0.163 & 0.641 & 0.085 & 0.712 & 0.819 & 0.436 \\
\hline $\begin{array}{l}\text { Vulnerability Measure } 100 \\
\text { (based on } 100 \% \text { of the poverty } \\
\text { line) }\end{array}$ & 0.753 & 0.788 & 0.401 & 0.773 & 0.932 & 0.419 & 0.842 & 0.473 & 0.990 & 0.998 & 0.731 \\
\hline $\begin{array}{l}\text { Vulnerability Measure } 120 \\
\text { (based on } 120 \% \text { of the poverty } \\
\text { line) }\end{array}$ & 0.911 & 0.884 & 0.693 & 0.830 & 0.973 & 0.648 & 0.924 & 0.817 & 1.000 & 1.000 & 0.874 \\
\hline No. of Observations & 138 & 126 & 109 & 108 & 104 & 87 & 77 & 42 & 29 & 28 & 1640 \\
\hline
\end{tabular}

Table 4 - Poverty and Vulnerability by Ethnic Group in Vietnam in 2004

\begin{tabular}{|c|c|c|c|c|c|c|c|c|c|c|}
\hline & Total & Majority & Kinh & Chinese & Minority & Tay & Thai & Khmer & Muong & Nung \\
\hline Real Consumption per capita & 4824 & 5169 & 5160 & 6274 & 2799 & 3047 & 2347 & 4072 & 2707 & 2851 \\
\hline $\begin{array}{l}\text { Poverty Headcount } 80 \\
\text { (based on } 80 \% \text { of the poverty } \\
\text { line) }\end{array}$ & 0.146 & 0.093 & 0.092 & 0.158 & 0.463 & 0.336 & 0.677 & 0.212 & 0.509 & 0.278 \\
\hline $\begin{array}{l}\text { Poverty Headcount } 100 \\
\text { (based on } 100 \% \text { of the } \\
\text { poverty line) }\end{array}$ & 0.265 & 0.202 & 0.202 & 0.211 & 0.643 & 0.580 & 0.846 & 0.394 & 0.642 & 0.472 \\
\hline Poverty Headcount 120 & 0.397 & 0.337 & 0.337 & 0.263 & 0.759 & 0.706 & 0.954 & 0.636 & 0.774 & 0.611 \\
\hline
\end{tabular}




\begin{tabular}{|c|c|c|c|c|c|c|c|c|c|c|c|c|}
\hline $\begin{array}{l}\text { Vulnerability Measure } 80 \\
\text { (based on } 80 \% \text { of the poverty } \\
\text { line) }\end{array}$ & 0.049 & & 0.006 & 0.006 & 0.000 & & 0.311 & 0.271 & 0.584 & 0.000 & 0.459 & 0.062 \\
\hline $\begin{array}{l}\text { Vulnerability Measure } 100 \\
\text { (based on } 100 \% \text { of the } \\
\text { poverty line) }\end{array}$ & 0.144 & & 0.066 & 0.066 & 0.111 & & 0.622 & 0.667 & 0.919 & 0.131 & 0.746 & 0.527 \\
\hline $\begin{array}{l}\text { Vulnerability Measure } 120 \\
\text { (based on } 120 \% \text { of the } \\
\text { poverty line) }\end{array}$ & 0.332 & & 0.261 & 0.260 & 0.370 & & 0.768 & 0.829 & 0.969 & 0.448 & 0.868 & 0.741 \\
\hline No. of Observations & 9188 & & 7847 & 7787 & 63 & & 1341 & 291 & 186 & 84 & 132 & 84 \\
\hline Real Consumption per capita & 2389 & 1823 & 2351 & 2480 & 1779 & 2841 & 2490 & 3257 & 2815 & 2780 & 6790 & \\
\hline $\begin{array}{l}\text { Poverty Headcount } 80 \\
\text { (based on } 80 \% \text { of the poverty } \\
\text { line) }\end{array}$ & 0.538 & 0.842 & 0.625 & 0.400 & 1.000 & 0.200 & 0.182 & 1.000 & 0.000 & 0.333 & 0.081 & \\
\hline $\begin{array}{l}\text { Poverty Headcount } 100 \\
\text { (based on } 100 \% \text { of the } \\
\text { poverty line) }\end{array}$ & 0.846 & 0.895 & 0.750 & 0.800 & 1.000 & 0.533 & 0.545 & 1.000 & 0.000 & 0.667 & 0.141 & \\
\hline $\begin{array}{l}\text { Poverty Headcount } 120 \\
\text { (based on } 120 \% \text { of the } \\
\text { poverty line) }\end{array}$ & 0.923 & 0.947 & 0.750 & 0.800 & 1.000 & 0.600 & 0.727 & 1.000 & 1.000 & 1.000 & 0.214 & \\
\hline $\begin{array}{l}\text { Vulnerability Measure } 80 \\
\text { (based on } 80 \% \text { of the poverty } \\
\text { line) }\end{array}$ & 0.247 & 0.415 & 0.017 & 0.434 & 0.676 & 0.421 & 0.350 & 0.250 & 0.382 & 0.350 & 0.041 & \\
\hline $\begin{array}{l}\text { Vulnerability Measure } 100 \\
\text { (based on } 100 \% \text { of the }\end{array}$ & 0.508 & 0.604 & 0.624 & 0.600 & 1.000 & 0.667 & 0.577 & 0.607 & 1.000 & 1.000 & 0.102 & \\
\hline
\end{tabular}


poverty line)

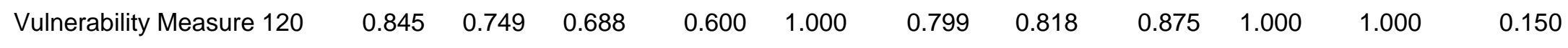
(based on $120 \%$ of the poverty line)

No. of Observations

$\begin{array}{lll}55 & 34 & 24\end{array}$

$17 \quad 26$

$18 \quad 28$

$14 \quad 6 \quad 6$

2731

Table 5 - Household Characteristics by Ethnic Group in 2002

\begin{tabular}{|c|c|c|c|c|c|c|c|c|c|c|}
\hline & Total & Majority & Kinh & Chinese & Minority & Tay & Thai & Khmer & Muong & Nung \\
\hline \multicolumn{11}{|l|}{ Household Characteristics } \\
\hline Age of Household Head & 47.55 & 48.24 & 48.31 & 51.87 & 43.22 & 41.88 & 42.14 & 50.34 & 42.32 & 41.55 \\
\hline Household Size & 4.48 & 4.34 & 4.37 & 4.74 & 5.35 & 4.93 & 5.73 & 4.83 & 4.96 & 5.10 \\
\hline Dependency Burden & 0.38 & 0.37 & 0.38 & 0.36 & 0.42 & 0.40 & 0.40 & 0.37 & 0.38 & 0.39 \\
\hline \multicolumn{11}{|c|}{$\begin{array}{l}\text { Maximum Educational Attainment }{ }^{*} \text { (The share of the household whose maximum educational attainment is Primary School, Lower Secondary School } \\
\text { etc.) }\end{array}$} \\
\hline Primary School & 0.242 & 0.227 & 0.230 & 0.292 & 0.331 & 0.253 & 0.361 & 0.362 & 0.342 & 0.348 \\
\hline Lower Secondary School & 0.319 & 0.332 & 0.328 & 0.259 & 0.239 & 0.342 & 0.280 & 0.200 & 0.362 & 0.348 \\
\hline Upper Secondary School & 0.170 & 0.183 & 0.181 & 0.203 & 0.088 & 0.154 & 0.041 & 0.108 & 0.156 & 0.096 \\
\hline Technical School & 0.084 & 0.088 & 0.087 & 0.052 & 0.060 & 0.108 & 0.090 & 0.012 & 0.044 & 0.074 \\
\hline Higher Education & 0.071 & 0.078 & 0.078 & 0.033 & 0.025 & 0.035 & 0.035 & 0.012 & 0.031 & 0.013 \\
\hline Land $\left(\mathrm{m}^{2}\right)$ & 6089 & 4528 & 4603 & 5242 & 15843 & 18073 & 13930 & 9287 & 11481 & 12662 \\
\hline Agricultural Land $\left(\mathrm{m}^{2}\right)$ & 4480 & 3749 & 3822 & 4035 & 9048 & 5499 & 10408 & 8416 & 6236 & 5509 \\
\hline Sylvicultural Land $\left(\mathrm{m}^{2}\right)$ & 1233 & 393 & 414 & 255 & 6479 & 12297 & 3232 & 158 & 5078 & 7052 \\
\hline Aquacultural water $\left(\mathrm{m}^{2}\right)$ & 311 & 339 & 320 & 788 & 131 & 142 & 174 & 593 & 138 & 83 \\
\hline Unused Land $\left(\mathrm{m}^{2}\right)$ & 65 & 46 & 48 & 165 & 186 & 135 & 116 & 120 & 29 & 18 \\
\hline
\end{tabular}




\begin{tabular}{|c|c|c|c|c|c|c|c|c|c|c|c|}
\hline & Dao & Ngai & Ede & Coho & Bana & Sandiu & Sedang & Stieng & Gietrieg & Stingmun & Other \\
\hline \multicolumn{12}{|l|}{ Household Characteristics } \\
\hline Age of Household Head & 39.86 & 44.94 & 46.63 & 46.07 & 42.52 & 40.72 & 47.31 & 46.00 & 46.62 & 41.50 & 43.17 \\
\hline Household Size & 5.54 & 6.19 & 6.30 & 5.78 & 5.78 & 4.94 & 5.56 & 5.67 & 5.45 & 5.25 & 4.96 \\
\hline \multirow[t]{2}{*}{ Dependency Burden } & 0.43 & 0.51 & 0.47 & 0.45 & 0.49 & 0.42 & 0.46 & 0.49 & 0.49 & 0.50 & 0.41 \\
\hline & Dao & Ngai & Ede & Coho & Bana & Sandiu & Sedang & Stieng & Gietrieg & Stingmun & Other \\
\hline \multicolumn{12}{|l|}{$\begin{array}{l}\text { Maximum Educational } \\
\text { Attainment }\end{array}$} \\
\hline Primary & 0.362 & 0.405 & 0.394 & 0.398 & 0.260 & 0.322 & 0.390 & 0.190 & 0.517 & 0.500 & 0.284 \\
\hline Lower Secondary & 0.065 & 0.127 & 0.239 & 0.130 & 0.029 & 0.322 & 0.078 & 0.024 & 0.103 & 0.071 & 0.260 \\
\hline Upper Secondary & 0.022 & 0.008 & 0.064 & 0.102 & 0.010 & 0.115 & 0.013 & 0.024 & 0.000 & 0.000 & 0.108 \\
\hline Technical School & 0.007 & 0.040 & 0.037 & 0.000 & 0.010 & 0.126 & 0.026 & 0.000 & 0.000 & 0.000 & 0.076 \\
\hline Higher Education & 0.022 & 0.016 & 0.000 & 0.019 & 0.000 & 0.034 & 0.000 & 0.000 & 0.000 & 0.000 & 0.040 \\
\hline Land $\left(\mathrm{m}^{2}\right)$ & 40149 & 18053 & 16076 & 11434 & 14680 & 9402 & 15892 & 24779 & 12706 & 19023 & 12037 \\
\hline Agricultural Land $\left(\mathrm{m}^{2}\right)$ & 14050 & 15274 & 15931 & 11221 & 12741 & 3245 & 11721 & 24660 & 12529 & 17692 & 8069 \\
\hline Sylvicultural Land $\left(\mathrm{m}^{2}\right)$ & 25582 & 44 & 124 & 0 & 1936 & 6097 & 2305 & 0 & 86 & 1250 & 3491 \\
\hline Aquacultural water $\left(\mathrm{m}^{2}\right)$ & 34 & 0 & 21 & 0 & 3 & 30 & 1650 & 0 & 5 & 81 & 416 \\
\hline Unused Land $\left(\mathrm{m}^{2}\right)$ & 483 & 2735 & 0 & 213 & 0 & 30 & 216 & 119 & 86 & 0 & 61 \\
\hline
\end{tabular}




\section{Methodologies}

\subsection{Determinants of Consumption}

First, we estimate $\ln \mathrm{W}_{\mathrm{ijk}}$ or log of per capita expenditure of the $i$-th household in the $j$-th ethnic group (e.g. majority, minority, the Kinh, or the Khmer) living in the $k$-th commune taking into account a vector of socio-economic characteristics, $\mathrm{X}_{\mathrm{ijk}}$, commune-level fixed effects, $\eta_{\mathrm{ij}}$, and a random error term, $\varepsilon_{\mathrm{ijk}}$, which is orthogonal to the explanatory variables. $\alpha_{\mathrm{j}}$ is a constant error term.

$$
\ln \mathrm{W}_{\mathrm{ijk}}=\alpha_{\mathrm{j}}+\mathrm{X}_{\mathrm{ijk}} \beta_{\mathrm{j}}+\eta_{\mathrm{ij}}+\varepsilon_{\mathrm{ijk}} \quad \mathrm{i}=1, \ldots, \mathrm{N}, \mathrm{k}=1, \ldots, \mathrm{K}, \mathrm{j}=1, \ldots, \mathrm{n}
$$

$\mathrm{X}_{\mathrm{ijk}}$ includes age of household head, the share of female household members, dependency burden (the share of members whose age is below 15 years old or above 65 years old), whether a household head is married, the maximum educational attainment of household members, and areas of owned land and its square (for agricultural land, sylvicultural land, aquacultural water, unused land).

In an alternative specification, the commune fixed effects are dropped, as shown below:

$$
\ln \mathrm{W}_{\mathrm{ij}}=\alpha_{\mathrm{j}}+\mathrm{X}_{\mathrm{ij}} \beta_{1 \mathrm{j}}+\mathrm{D}_{\mathrm{j}} \beta_{2 \mathrm{j}}+\varepsilon_{\mathrm{ij}}
$$

where a vector of dummy variables, $\mathrm{D}_{\mathrm{j}}$, namely regional dummy variables (e.g. whether a household is living in High Mountains, Coastal Area etc.) and dummy variables on religion (e.g. whether the main religion for the commune is Buddhism) are added.

\subsection{Determinants of Poverty}

Here the same set of explanatory variables is used to analyse the determinants of poverty. The dependent variable is whether a household's expenditure is below $(=1)$ or above $(=0)$ the national poverty line.

To take account of commune fixed effects, a conditional fixed-effects logistic model is applied as follows. ${ }^{9}$

\footnotetext{
${ }^{9}$ A fixed-effects logistic model is chosen, as a fixed-effects probit model cannot be estimated by standard commands available in Stata.
} 


$$
P\left(y_{i k j}=1 \mid \eta_{i j}^{\prime}, \beta_{j}^{\prime}\right)=\frac{\exp \left(\eta_{i j}^{\prime}+X_{i k j}\right)}{1+\exp \left(\eta_{i j}^{\prime}+X_{i k j}\right)}
$$

$\eta_{\mathrm{ij}}^{\prime}$ is the commune fixed effects as above. Alternatively, a probit model is applied without commune fixed effects, but with regional dummies (e.g. whether a household is located in high mountains).

$$
\begin{aligned}
& \mathrm{P}\left(\mathrm{y}_{\mathrm{ij}}=1 \mid \beta_{\mathrm{j}}^{\prime}\right)=\int_{\infty}^{\beta_{\mathrm{j}}^{\prime}} \phi(\mathrm{t}) \mathrm{dt} \\
& =\Phi\left(\beta_{\mathrm{j}}^{\prime} \mathrm{X}_{\mathrm{ij}}\right)
\end{aligned}
$$

The function $\Phi($.$) denotes the standard normal distribution.$

\subsection{Decomposition of Expenditure and Poverty}

A decomposition analysis of the differences in poverty (or of the expected probability of poverty) and expenditure of ethnic majority and minorities is carried out. As noted earlier, this relies on the Oaxaca-Blinder (1973) decomposition of the wage difference into two components: the characteristic component, associated with the average levels of characteristics (e.g. education), and the structural component, related to returns to these characteristics.

Let us first consider the poverty decomposition. Denoting the average (predicted) probability of being poor among the ethnic majority groups and ethnic minority groups as $\overline{\mathrm{P}}_{\text {maj }}$ and $\overline{\mathrm{P}}_{\text {min }}$, respectively, the decomposition is obtained as:

$$
\overline{\mathrm{P}}_{\text {maj }}-\overline{\mathrm{P}}_{\text {min }}=\left\lfloor\mathrm{p}\left(\overline{\mathrm{X}}_{\text {maj }}, \hat{\beta}_{\text {maj }}\right)-\mathrm{p}\left(\overline{\mathrm{X}}_{\text {min }}, \hat{\beta}_{\text {maj }}\right)\right]+\left\lfloor\mathrm{p}\left(\overline{\mathrm{X}}_{\text {min }}, \hat{\beta}_{\text {maj }}\right)-\mathrm{p}\left(\overline{\mathrm{X}}_{\text {min }}, \hat{\beta}_{\text {min }}\right)\right\rfloor
$$

Here the subscript, $\mathrm{i}$, j or $\mathrm{k}$, is suppressed to make the notation simpler. It is noted that the first bracket contains the characteristics component and the second the structural component. In the first component, the differences in characteristics are evaluated using the coefficient estimates for the ethnic majority groups $\left(\hat{\beta}_{\text {maj }}\right)$ as the reference group. In the second, the characteristics of the ethnic minority groups are evaluated taking into account the differences between $\hat{\beta}_{\text {maj }}$ and $\hat{\beta}_{\text {min }}$. The second component is sometimes considered a measure of 'discrimination'. Along the lines of Kijima (2006), two observations are in order: (i) the first 
component, based on differences in characteristics, could itself reflect discrimination over a period; and (ii) the lower returns to land among the ethnic minorities, on the other hand, could be lower simply because of locational disadvantages. This implies that this component could be non-zero even if there is no discrimination in the sample year.

In order to disaggregate the characteristics and structural components, we take advantage of a decomposition procedure proposed by Yun (2004). All that is needed is to disaggregate the characteristics and structural components using two sets of weights.

$$
\begin{aligned}
& \omega_{\Delta x}{ }^{i}=\frac{\left(\bar{X}^{i}{ }_{\text {maj }}-\bar{X}_{\text {min }}{ }^{i}\right) \hat{\beta}^{i}{ }_{\text {maj }}}{\left(\bar{X}_{\text {maj }}-\bar{X}_{\text {min }}\right)},
\end{aligned}
$$

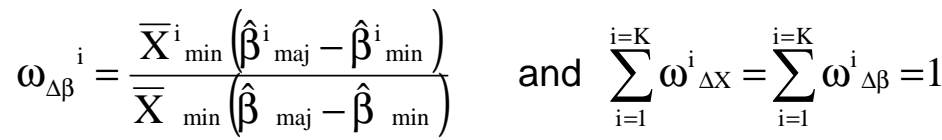

These weights are defined for individual variables, $\mathrm{i}=1,2, \ldots, \mathrm{K}$, and add up to 1 .

\section{Results}

\subsection{Regression Results}

In this section, we will discuss the econometric results obtained from the model specifications in Section 3. First, the key findings are summarised.

Table 6 contains the results on the determinants of log of per capita expenditure by each ethnic group in 2002, with commune fixed effects.

First, the pattern of the regression results is generally similar for ethnic majority and minority groups. For example, in both cases, the coefficient of 'dependency burden' is negative and highly significant. That of 'whether a household head is married' is also negative and significant. ${ }^{10}$ On the other hand, the coefficients are positive and significant for both educational attainments higher than primary schooling and land areas for all the different categories. Square of land in each category is negative and significant, which suggests that the effect of land on expenditure is non-linear.

Second, a few differences in the regression results across different ethnic minority groups may be noted. For example, the coefficient of the share of female members is negative and

\footnotetext{
${ }^{10}$ It is not clear why a household with a married household head has lower per capita consumption. Because this dummy variable is negatively correlated with the head's age (with the correlation coefficient -0.35 ) and positively correlated with household size (with the correlation coefficient 0.27 ), the sample of married household heads is likely to include relatively young couples dependent on low income of the husband.
} 
significant for the Khmer, the Muong, and the Nung, but positive and significant for the Gietrieng, and not significant for others. Education is not a significant determinant for the Khmer and some other minority groups.

Table 7 contains the results based on the specification without commune effects, but with regional and religion dummies, using the data for 2002. Disaggregation by each ethnic group is not carried out as the regional dummies cannot be included in smaller samples. The results are not much different from those given in Table 6. As expected, the coefficient estimates for the Buddhists and for those inhabiting Inland Delta or Coastal Area are positive and significant. The coefficients of the dummies for high and low mountains are negative and significant. These results are also used for the decomposition analysis.

Tables 8 and 9 contain the results obtained from the data for 2004, with and without commune effects, respectively. Note that these tables are not strictly comparable as the data for 2002 and 2004 are 'repeated cross-sectional data', rather than panel data, and only a part (or about $16 \%$ ) of the households in the 2002 data was resurveyed in 2004. Short and selective comments are given below. 
Table 6 - Determinants of log of per capita Consumption by Ethnic Group in 2002 (with Commune Fixed Effects)

\begin{tabular}{|c|c|c|c|c|c|c|c|c|c|c|}
\hline & Total & Majority & Kinh & Chinese & Minority & Tay & Thai & Khmer & Muong & Nung \\
\hline & $\begin{array}{l}\text { Coef. } \\
\text { (t value) }\end{array}$ & $\begin{array}{l}\text { Coef. } \\
\text { (t value) }\end{array}$ & $\begin{array}{l}\text { Coef. } \\
\text { (t value) }\end{array}$ & $\begin{array}{l}\text { Coef. } \\
\text { (t value) }\end{array}$ & $\begin{array}{l}\text { Coef. } \\
\text { (t value) }\end{array}$ & $\begin{array}{l}\text { Coef. } \\
\text { (t value) }\end{array}$ & $\begin{array}{l}\text { Coef. } \\
\text { (t value) }\end{array}$ & $\begin{array}{l}\text { Coef. } \\
\text { (t value) }\end{array}$ & $\begin{array}{l}\text { Coef. } \\
\text { (t value) }\end{array}$ & $\begin{array}{l}\text { Coef. } \\
\text { (t value) }\end{array}$ \\
\hline Age of Household head & $\begin{array}{l}0.001 \\
(4.07)^{\star \star}\end{array}$ & $\begin{array}{l}0.001 \\
(3.68)^{\star \star}\end{array}$ & $\begin{array}{l}0.001 \\
(3.46)^{\star \star}\end{array}$ & $\begin{array}{l}-0.005 \\
(1.85)\end{array}$ & $\begin{array}{l}0.00 \\
(0.05)\end{array}$ & $\begin{array}{l}0.002 \\
(2.42)^{\star}\end{array}$ & $\begin{array}{l}-0.003 \\
(2.36)^{\star}\end{array}$ & $\begin{array}{l}0.002 \\
(0.87)\end{array}$ & $\begin{array}{l}0.002 \\
(1.46)\end{array}$ & $\begin{array}{l}-0.004 \\
(1.52)\end{array}$ \\
\hline $\begin{array}{l}\text { The Share of Female } \\
\text { Members }\end{array}$ & $\begin{array}{l}-0.022 \\
(1.85)\end{array}$ & $\begin{array}{l}-0.025 \\
(1.95)\end{array}$ & $\begin{array}{l}-0.029 \\
(2.20)^{\star}\end{array}$ & $\begin{array}{l}0.059 \\
(0.35)\end{array}$ & $\begin{array}{l}-0.024 \\
(0.75)\end{array}$ & $\begin{array}{l}-0.115 \\
(1.78)\end{array}$ & $\begin{array}{l}-0.133 \\
(1.39)\end{array}$ & $\begin{array}{l}0.591 \\
(4.21)^{\star \star}\end{array}$ & $\begin{array}{l}-0.197 \\
(2.02)^{\star}\end{array}$ & $\begin{array}{l}0.311 \\
(2.10)^{\star}\end{array}$ \\
\hline Dependency Burden & $\begin{array}{l}-0.319 \\
(31.21)^{\star \star}\end{array}$ & $\begin{array}{l}-0.32 \\
(29.18)^{\star \star}\end{array}$ & $\begin{array}{l}-0.31 \\
(28.04)^{\star \star}\end{array}$ & $\begin{array}{l}-0.317 \\
(1.81)\end{array}$ & $\begin{array}{l}-0.325 \\
(11.45)^{\star \star}\end{array}$ & $\begin{array}{l}-0.274 \\
(4.75)^{\star \star}\end{array}$ & $\begin{array}{l}-0.429 \\
(4.75)^{\star \star}\end{array}$ & $\begin{array}{l}-0.38 \\
(3.31)^{\star \star}\end{array}$ & $\begin{array}{l}-0.403 \\
(4.81)^{\star \star}\end{array}$ & $\begin{array}{l}-0.511 \\
(4.02)^{\star \star}\end{array}$ \\
\hline $\begin{array}{l}\text { Whether a head is } \\
\text { married }\end{array}$ & $\begin{array}{l}-0.024 \\
(3.43)^{\star \star}\end{array}$ & $\begin{array}{l}-0.017 \\
(2.37)^{\star}\end{array}$ & $\begin{array}{l}-0.02 \\
(2.64)^{\star \star}\end{array}$ & $\begin{array}{l}-0.145 \\
(1.52)\end{array}$ & $\begin{array}{l}-0.066 \\
(3.48)^{\star \star}\end{array}$ & $\begin{array}{l}-0.036 \\
(0.90)\end{array}$ & $\begin{array}{l}-0.069 \\
(0.95)\end{array}$ & $\begin{array}{l}-0.015 \\
(0.20)\end{array}$ & $\begin{array}{l}-0.044 \\
(0.82)\end{array}$ & $\begin{array}{l}-0.224 \\
(2.22)^{\star}\end{array}$ \\
\hline Primary School & -0.019 & -0.047 & -0.035 & -0.039 & 0.035 & 0.02 & 0.125 & -0.009 & -0.027 & 0.044 \\
\hline $\begin{array}{l}\text { (Max. attainment of } \\
\text { members) }\end{array}$ & $(2.03)^{*}$ & $(4.45)^{\star \star}$ & $(3.33)^{\star \star}$ & $(0.36)$ & $(2.15)^{*}$ & $(0.43)$ & $(2.74)^{\star \star}$ & $(0.14)$ & $(0.40)$ & $(0.49)$ \\
\hline $\begin{array}{l}\text { Lower Secondary } \\
\text { School }\end{array}$ & 0.07 & 0.03 & 0.05 & $(0.03)$ & 0.13 & 0.11 & 0.21 & 0.01 & 0.08 & 0.23 \\
\hline $\begin{array}{l}\text { (Max. attainment of } \\
\text { members) }\end{array}$ & $(7.32)^{\star \star}$ & $(3.04)^{\star \star}$ & $(4.53)^{\star \star}$ & $(0.28)$ & $(6.73)^{\star \star}$ & $(2.37)^{\star}$ & $(4.04)^{\star \star}$ & $(0.09)$ & $(1.15)$ & $(2.41)^{\star}$ \\
\hline $\begin{array}{l}\text { Upper Secondary } \\
\text { School }\end{array}$ & 0.203 & 0.17 & 0.189 & 0.125 & 0.233 & 0.194 & 0.298 & 0.146 & 0.202 & 0.323 \\
\hline $\begin{array}{l}\text { (Max. attainment of } \\
\text { members) }\end{array}$ & $(19.15)^{\star \star}$ & $(14.36)^{\star \star}$ & $(15.93)^{\star \star}$ & $(1.03)$ & $(9.03)^{\star \star}$ & $(3.62)^{\star \star}$ & $(3.31)^{\star \star}$ & $(1.39)$ & $(2.64)^{\star \star}$ & $(2.75)^{\star \star}$ \\
\hline (Max. attainment of & $\begin{array}{l}0.344 \\
(27.68)^{\star \star}\end{array}$ & $\begin{array}{l}0.312 \\
(22.57)^{\star \star}\end{array}$ & $\begin{array}{l}0.337 \\
(24.33)^{\star \star}\end{array}$ & $\begin{array}{l}0.454 \\
(1.58)\end{array}$ & $\begin{array}{l}0.354 \\
(11.83)^{\star \star}\end{array}$ & $\begin{array}{l}0.332 \\
(5.71)^{\star \star}\end{array}$ & $\begin{array}{l}0.306 \\
(4.10)^{\star \star}\end{array}$ & $\begin{array}{l}-0.323 \\
(1.03)\end{array}$ & $\begin{array}{l}0.278 \\
(2.67)^{\star \star}\end{array}$ & $\begin{array}{l}0.746 \\
(6.29)^{\star \star}\end{array}$ \\
\hline
\end{tabular}


members)

\begin{tabular}{|c|c|c|c|c|c|c|c|c|c|c|}
\hline Higher Education & 0.51 & 0.473 & 0.494 & 0.723 & 0.576 & 0.618 & 0.511 & -0.025 & 0.648 & 1.012 \\
\hline $\begin{array}{l}\text { (Max. attainment of } \\
\text { members) }\end{array}$ & $(38.09)^{\star \star}$ & $(32.45)^{\star \star}$ & $(33.78)^{\star \star}$ & $(3.37)^{\star \star}$ & $(12.99)^{\star \star}$ & $(7.82)^{\star \star}$ & $(5.18)^{\star \star}$ & $(0.10)$ & $(5.61)^{\star \star}$ & $(4.61)^{\star \star}$ \\
\hline \multirow[t]{2}{*}{ Agricultural Land } & 6.092 & 6.886 & 6.672 & -17.111 & 8.166 & 2.647 & 1.303 & 19.953 & 5.868 & -8.058 \\
\hline & $(16.18)^{\star \star}$ & $(15.91)^{\star \star}$ & $(15.58)^{\star \star}$ & $(1.01)$ & $(7.76)^{\star \star}$ & $(0.44)$ & $(0.40)$ & $(5.63)^{\star *}$ & $(0.77)$ & $(0.42)$ \\
\hline \multirow[t]{2}{*}{ [Agricultural land] $^{2}$} & -6.471 & -7.136 & -6.909 & 589.267 & -45.069 & 39.365 & -7.995 & -74.497 & -110.622 & 837.462 \\
\hline & $(10.16)^{\star \star}$ & $(10.49)^{\star \star}$ & $(10.19)^{\star \star}$ & $(1.46)$ & $(6.85)^{\star \star}$ & $(0.27)$ & $(0.43)$ & $(5.04)^{\star \star}$ & $(0.74)$ & $(0.74)$ \\
\hline \multirow[t]{2}{*}{ Sylvicultural land } & 2.404 & 6.362 & 6.269 & -271.415 & 1.915 & 0.664 & -0.309 & 71.433 & 4.574 & 12.507 \\
\hline & $(4.31)^{\star \star}$ & $(4.13)^{\star \star}$ & $(4.27)^{\star \star}$ & $(1.87)$ & $(3.30)^{\star \star}$ & $(0.53)$ & $(0.05)$ & $(0.71)$ & $(1.41)$ & $(2.12)^{*}$ \\
\hline \multirow[t]{2}{*}{ [Sylvicultural land] $^{2}$} & -5.679 & -46.526 & -40.708 & $16,690.70$ & -4.099 & -2.357 & 81.68 & $-8,061.68$ & -33.688 & -142.466 \\
\hline & $(2.81)^{\star \star}$ & $(3.03)^{\star \star}$ & $(3.03)^{\star \star}$ & $(1.60)$ & $(2.16)^{\star}$ & $(0.25)$ & $(0.85)$ & $(0.63)$ & $(0.85)$ & $(1.49)$ \\
\hline \multirow[t]{2}{*}{ Aquacultural water } & 8.774 & 8.925 & 10.873 & -55.323 & 88.384 & 58.511 & 309.895 & 11.071 & 37.122 & 220.507 \\
\hline & $(6.61)^{\star \star}$ & $(6.24)^{\star \star}$ & $(5.08)^{\star \star}$ & $(1.04)$ & $(3.77)^{\star \star}$ & $(1.34)$ & $(2.47)^{\star}$ & $(0.29)$ & $(0.66)$ & $(0.89)$ \\
\hline \multirow[t]{2}{*}{ [Aquacultural water]2 } & -18.884 & -19.146 & -62.156 & $3,308.70$ & $-3,778.56$ & $-2,391.10$ & $-23,362.43$ & -181.402 & $-3,299.39$ & $-20,773.59$ \\
\hline & $(5.99)^{\star \star}$ & $(5.76)^{\star \star}$ & $(1.82)$ & $(1.25)$ & $(3.47)^{\star \star}$ & $(1.30)$ & $(0.30)$ & $(0.09)$ & $(1.11)$ & $(0.90)$ \\
\hline \multirow[t]{2}{*}{ Unused land } & -1.088 & 0.525 & -0.635 & 744.887 & -20.075 & -28.895 & -28.317 & 100.357 & -757.94 & -970.936 \\
\hline & $(0.30)$ & $(0.11)$ & $(0.13)$ & $(1.56)$ & $(1.76)$ & $(1.03)$ & $(0.68)$ & $(1.13)$ & $(1.46)$ & $(0.54)$ \\
\hline \multirow[t]{2}{*}{ [Unused land]2 } & 19.982 & -6.714 & 3.99 & 0 & $1,061.05$ & $2,174.44$ & $1,266.43$ & $-5,048.98$ & $127,620.73$ & $231,757.71$ \\
\hline & $(0.37)$ & $(0.11)$ & $(0.07)$ & (.) & $(1.84)$ & $(1.34)$ & $(0.54)$ & $(1.27)$ & $(1.47)$ & $(0.51)$ \\
\hline \multirow[t]{2}{*}{ Constant } & 7.915 & 8.015 & 7.993 & 8.649 & 7.476 & 7.456 & 7.651 & 7.418 & 7.448 & 7.707 \\
\hline & (472.93) & $(425.29)$ & $(423.77)$ & $(34.71)$ & (199.78) & (89.66) & $(64.05)$ & $(44.45)$ & $(61.58)$ & $(39.28)$ \\
\hline Observations & 29530 & 25456 & 25108 & 212 & 4074 & 1045 & 510 & 260 & 450 & 230 \\
\hline R-squared & 0.17 & 0.17 & 0.17 & 0.3 & 0.16 & 0.16 & 0.22 & 0.26 & 0.26 & 0.4 \\
\hline \multirow{2}{*}{ Joint Significance F Test } & $F(17,26621)$ & $F(17,22780)$ & $F(17,22623)$ & $F(16,101)$ & $F(17,3452)$ & $F(17,933)$ & $F(17,443)$ & $F(17,215)$ & $F(17,387)$ & $F(17,187)$ \\
\hline & $=313.69^{* *}$ & $=271.11^{* *}$ & $=271.50^{\star \star}$ & $=2.69^{\star *}$ & $=39.57^{\star \star}$ & $=10.69^{\star *}$ & $=7.23^{\star \star}$ & $=4.48^{\star \star}$ & $=7.82^{* *}$ & $=7.45^{\star \star}$ \\
\hline
\end{tabular}


* significant at 5\%; ** significant at 1\%, Significant coefficients are shown in bold.

Table 6 - Determinants of log of per capita Consumption by Ethnic Group in 2002 (with Commune Fixed Effects) (cont.)

\begin{tabular}{|c|c|c|c|c|c|c|c|c|c|c|c|}
\hline & Dao & Ngai & Ede & Coho & Bana & Sandiu & Sedang & Stieng & Gietrieng & Singmun & $\begin{array}{l}\text { Other } \\
\text { Minority } \\
\text { Groups }\end{array}$ \\
\hline & $\begin{array}{l}\text { Coef. } \\
\text { (t value) }\end{array}$ & $\begin{array}{l}\text { Coef. } \\
\text { (t value) }\end{array}$ & $\begin{array}{l}\text { Coef. } \\
\text { (t value) }\end{array}$ & $\begin{array}{l}\text { Coef. } \\
\text { (t value) }\end{array}$ & $\begin{array}{l}\text { Coef. } \\
\text { (t value) }\end{array}$ & $\begin{array}{l}\text { Coef. } \\
\text { (t value) }\end{array}$ & $\begin{array}{l}\text { Coef. } \\
\text { (t value) }\end{array}$ & $\begin{array}{l}\text { Coef. } \\
\text { (t value) }\end{array}$ & $\begin{array}{l}\text { Coef. } \\
\text { (t value) }\end{array}$ & $\begin{array}{l}\text { Coef. } \\
\text { (t value) }\end{array}$ & $\begin{array}{l}\text { Coef. } \\
\text { (t value) }\end{array}$ \\
\hline $\begin{array}{l}\text { Age of } \\
\text { Household head }\end{array}$ & $\begin{array}{l}-0.001 \\
(0.35)\end{array}$ & $\begin{array}{l}0.001 \\
(0.54)\end{array}$ & $\begin{array}{l}0.001 \\
(0.46)\end{array}$ & $\begin{array}{l}0.002 \\
(0.68)\end{array}$ & $\begin{array}{l}0.002 \\
(0.74)\end{array}$ & $\begin{array}{l}-0.001 \\
(0.33)\end{array}$ & $\begin{array}{l}-0.001 \\
(0.90)\end{array}$ & $\begin{array}{l}0.006 \\
(1.82)\end{array}$ & $\begin{array}{l}0.005 \\
(1.82)\end{array}$ & $\begin{array}{l}0.004 \\
(0.75)\end{array}$ & $\begin{array}{l}-0.001 \\
(1.43)\end{array}$ \\
\hline $\begin{array}{l}\text { The Share of } \\
\text { Female } \\
\text { Members }\end{array}$ & $\begin{array}{l}0.107 \\
(0.74)\end{array}$ & $\begin{array}{l}-0.001 \\
(0.01)\end{array}$ & $(0.04)$ & $(1.99)^{\star}$ & $(0.40)$ & $(0.28)$ & $(1.24)$ & $(0.67)$ & $(2.38)^{\star}$ & $(0.46)$ & $\begin{array}{l}0.062 \\
(1.26)\end{array}$ \\
\hline $\begin{array}{l}\text { Dependency } \\
\text { Burden }\end{array}$ & $\begin{array}{l}-0.423 \\
(3.73)^{\star \star}\end{array}$ & $\begin{array}{l}-0.366 \\
(2.42)^{\star}\end{array}$ & $\begin{array}{l}-0.585 \\
(3.32)^{\star \star}\end{array}$ & $\begin{array}{l}-0.291 \\
(1.61)\end{array}$ & $\begin{array}{l}-0.538 \\
(3.01)^{\star \star}\end{array}$ & $\begin{array}{l}-0.541 \\
(2.35)^{\star}\end{array}$ & $\begin{array}{l}-0.307 \\
(2.53)^{\star}\end{array}$ & $\begin{array}{l}0.085 \\
(0.32)\end{array}$ & $\begin{array}{l}-0.764 \\
(2.23)^{\star}\end{array}$ & $\begin{array}{l}-0.072 \\
(0.13)\end{array}$ & $\begin{array}{l}-0.447 \\
(10.39)^{\star \star}\end{array}$ \\
\hline $\begin{array}{l}\text { Whether a head } \\
\text { is married }\end{array}$ & $\begin{array}{l}0.071 \\
(0.81)\end{array}$ & $\begin{array}{l}-0.02 \\
(0.24)\end{array}$ & $\begin{array}{l}0.166 \\
(1.35)\end{array}$ & $\begin{array}{l}-0.199 \\
(1.68)\end{array}$ & $\begin{array}{l}-0.044 \\
(0.51)\end{array}$ & $\begin{array}{l}-0.023 \\
(0.16)\end{array}$ & $\begin{array}{l}-0.245 \\
(3.19)^{\star \star}\end{array}$ & $\begin{array}{l}0.042 \\
(0.26)\end{array}$ & $\begin{array}{l}0 \\
0.00\end{array}$ & $\begin{array}{l}0.094 \\
(0.26)\end{array}$ & $\begin{array}{l}-0.074 \\
(2.44)^{\star}\end{array}$ \\
\hline $\begin{array}{l}\text { Primary School } \\
\text { (Max. attainment } \\
\text { of members) }\end{array}$ & $\begin{array}{l}0.127 \\
(2.42)^{\star}\end{array}$ & $\begin{array}{l}-0.01 \\
(0.19)\end{array}$ & $\begin{array}{l}0.036 \\
(0.42)\end{array}$ & $\begin{array}{l}0.052 \\
(0.50)\end{array}$ & $\begin{array}{l}0.09 \\
(1.34)\end{array}$ & $\begin{array}{l}0.446 \\
(2.74)^{\star \star}\end{array}$ & $\begin{array}{l}0.057 \\
(1.06)\end{array}$ & $\begin{array}{l}-0.056 \\
(0.45)\end{array}$ & $\begin{array}{l}-0.13 \\
(1.09)\end{array}$ & $\begin{array}{l}0.044 \\
(0.31)\end{array}$ & $\begin{array}{l}0.025 \\
(0.80)\end{array}$ \\
\hline Lower & 0.19 & 0.10 & 0.07 & 0.10 & 0.32 & 0.33 & 0.13 & $(0.39)$ & 0.19 & 0.43 & 0.14 \\
\hline
\end{tabular}




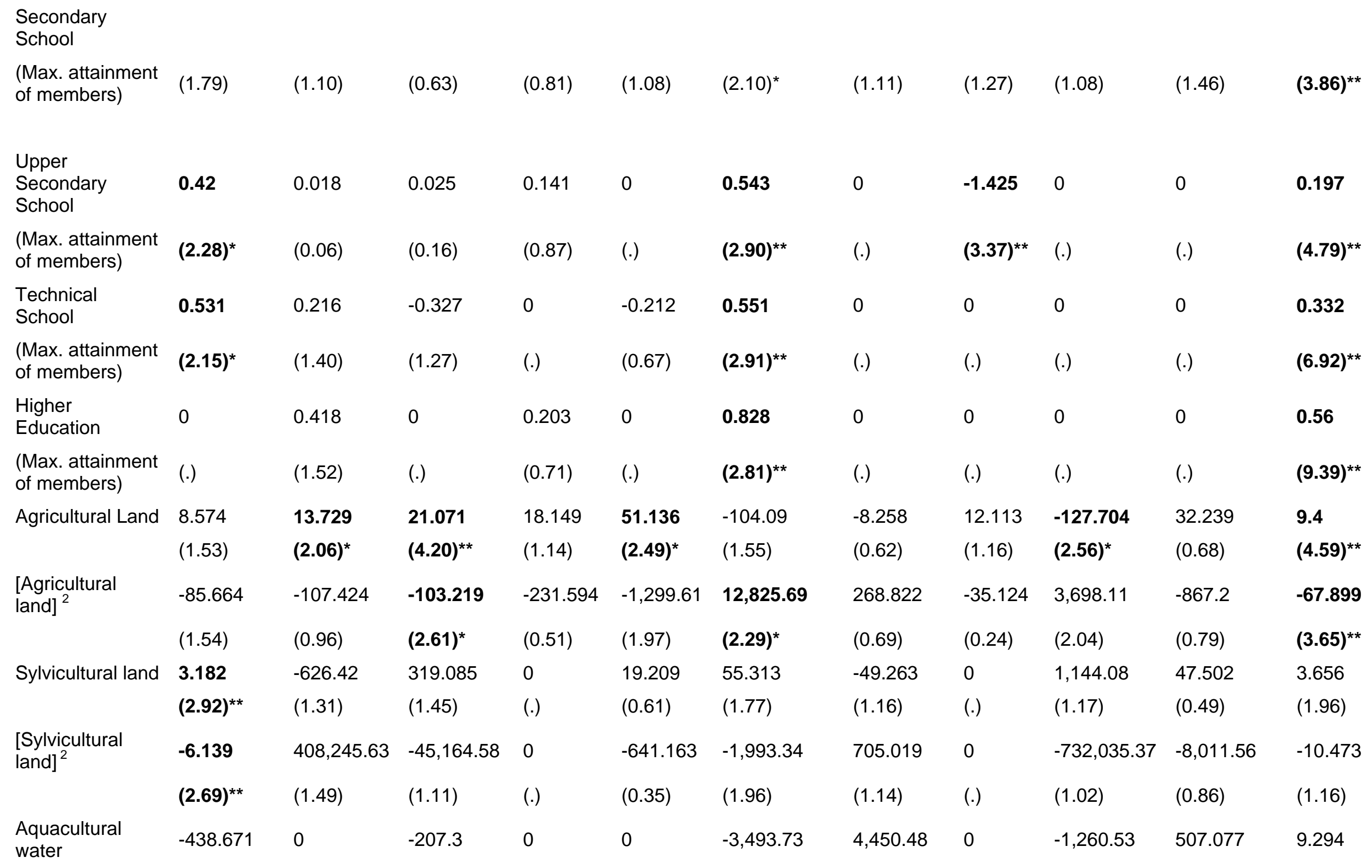




\begin{tabular}{|c|c|c|c|c|c|c|c|c|c|c|c|}
\hline $\begin{array}{l}\text { [Aquacultural } \\
\text { water]2 }\end{array}$ & $\begin{array}{l}508,590.80 \\
(0.44)\end{array}$ & $\begin{array}{l}0 \\
(.)\end{array}$ & $\begin{array}{l}981,358.63 \\
(0.36)\end{array}$ & $\begin{array}{l}0 \\
(.)\end{array}$ & $\begin{array}{l}0 \\
(.)\end{array}$ & $\begin{array}{l}17680441.72 \\
(1.47)\end{array}$ & $\begin{array}{l}-1.39 E+07 \\
(0.73)\end{array}$ & $\begin{array}{l}0 \\
(.)\end{array}$ & $\begin{array}{l}0 \\
(.)\end{array}$ & $\begin{array}{l}-248,128.52 \\
(0.43)\end{array}$ & $\begin{array}{l}-19.822 \\
(0.96)\end{array}$ \\
\hline Unused land & $\begin{array}{l}-31.106 \\
(1.32)\end{array}$ & $\begin{array}{l}-30.981 \\
(2.08)^{\star}\end{array}$ & $\begin{array}{l}0 \\
(.)\end{array}$ & $\begin{array}{l}3.28 \\
(0.20)\end{array}$ & $\begin{array}{l}0 \\
(.)\end{array}$ & $\begin{array}{l}-94,570.38 \\
(1.99)\end{array}$ & $\begin{array}{l}154.63 \\
(1.67)\end{array}$ & $\begin{array}{l}0 \\
(.)\end{array}$ & $\begin{array}{l}83.692 \\
(0.85)\end{array}$ & $\begin{array}{l}0 \\
(.)\end{array}$ & $\begin{array}{l}-24.053 \\
(0.86)\end{array}$ \\
\hline [Unused land]2 & $\begin{array}{l}2,493.47 \\
(1.72)\end{array}$ & $\begin{array}{l}1,660.39 \\
(2.47)^{\star}\end{array}$ & $\begin{array}{l}0 \\
(.)\end{array}$ & $\begin{array}{l}0 \\
(.)\end{array}$ & $\begin{array}{l}0 \\
(.)\end{array}$ & $\begin{array}{l}1.18 \mathrm{E}+08 \\
(1.98)\end{array}$ & $\begin{array}{l}-17,836.46 \\
(1.94)\end{array}$ & $\begin{array}{l}0 \\
(.)\end{array}$ & $\begin{array}{l}0 \\
(.)\end{array}$ & $\begin{array}{l}0 \\
(.)\end{array}$ & $\begin{array}{l}777.17 \\
(0.73)\end{array}$ \\
\hline Constant & $\begin{array}{l}7.242 \\
(45.87)\end{array}$ & $\begin{array}{l}7.152 \\
(35.34)\end{array}$ & $\begin{array}{l}7.12 \\
(34.51)\end{array}$ & $\begin{array}{l}7.098 \\
(25.79)\end{array}$ & $\begin{array}{l}6.786 \\
(33.21)\end{array}$ & $\begin{array}{l}7.173 \\
(17.54)\end{array}$ & $\begin{array}{l}2,855.57 \\
(0.73)\end{array}$ & $\begin{array}{l}6.795 \\
(21.80)\end{array}$ & $\begin{array}{l}8.919 \\
(15.37)\end{array}$ & $\begin{array}{l}7 \\
(13.44)\end{array}$ & $\begin{array}{l}7.777 \\
(125.15)\end{array}$ \\
\hline Observations & 138 & 126 & 109 & 108 & 104 & 87 & 77 & 42 & 29 & 28 & 1640 \\
\hline R-squared & 0.37 & 0.33 & 0.39 & 0.19 & 0.22 & 0.57 & 0.37 & 0.49 & 0.73 & 0.36 & 0.19 \\
\hline $\begin{array}{l}\text { Joint } \\
\text { Significance F } \\
\text { Test }\end{array}$ & $\begin{array}{l}F(16,88) \\
=3.24\end{array}$ & $\begin{array}{l}F(15,91) \\
=2.98^{\star *}\end{array}$ & $\begin{array}{l}F(14,76) \\
=3.44^{\star \star}\end{array}$ & $\begin{array}{l}F(11,85) \\
=1.84\end{array}$ & $\begin{array}{l}F(11,82) \\
=2.07^{*}\end{array}$ & $\begin{array}{l}F(17,50) \\
=3.83^{* *}\end{array}$ & $\begin{array}{l}F(14,48) \\
=2.00^{\star *}\end{array}$ & $\begin{array}{l}F(9,25) \\
=2.64^{*}\end{array}$ & $\begin{array}{l}F(12,15) \\
=3.40^{*}\end{array}$ & $\begin{array}{l}F(12,14) \\
=0.65\end{array}$ & $\begin{array}{l}F(17,1437) \\
=19.53^{\star *}\end{array}$ \\
\hline Prob. >F & 0.0002 & 0.0007 & 0.0002 & 0.0588 & 0.0315 & 0.0001 & 0.0386 & 0.026 & 0.0129 & 0.7685 & 0.0000 \\
\hline $\begin{array}{l}\text { Number of } \\
\text { Communes }\end{array}$ & 34 & 20 & 19 & 12 & 11 & 20 & 15 & 8 & 2 & 2 & 186 \\
\hline
\end{tabular}

${ }^{*}$ significant at $5 \% ;{ }^{* *}$ significant at $1 \%$, Significant coefficients are shown in bold. 
Table 7 - Determinants of log of per capita Consumption by Ethnic Group in 2002

(without Commune Fixed Effects, with Regional Dummies)

\begin{tabular}{|c|c|c|c|}
\hline & Total & Majority & Minority \\
\hline \multirow[t]{2}{*}{ Age of Household head } & 0.002 & 0.001 & 0.001 \\
\hline & $(6.96)^{\star \star}$ & $(4.23)^{\star \star}$ & $(1.62)$ \\
\hline \multirow[t]{2}{*}{ The Share of Female Members } & -0.024 & -0.034 & -0.034 \\
\hline & $(1.56)$ & $(2.02)^{\star}$ & $(0.88)$ \\
\hline \multirow[t]{2}{*}{ Dependency Burden } & -0.411 & -0.431 & -0.375 \\
\hline & $(31.58)^{\star \star}$ & $(31.24)^{\star \star}$ & $(11.07)^{\star \star}$ \\
\hline \multirow{2}{*}{$\begin{array}{l}\text { Whether a household head is } \\
\text { married }\end{array}$} & -0.094 & -0.081 & -0.094 \\
\hline & $(10.72)^{\star \star}$ & $(8.63)^{\star \star}$ & $(4.12)^{\star *}$ \\
\hline Primary School & 0.086 & 0.005 & 0.14 \\
\hline (Max. attainment of members) & $(7.69)^{\star \star}$ & (0.39) & $(7.93)^{\star \star}$ \\
\hline Lower Secondary School & 0.17 & 0.05 & 0.31 \\
\hline (Max. attainment of members) & $(15.28)^{\star \star}$ & $(3.93)^{\star \star}$ & $(15.84)^{\star \star}$ \\
\hline Upper Secondary School & 0.409 & 0.3 & 0.45 \\
\hline (Max. attainment of members) & $(33.44)^{\star \star}$ & $(21.30)^{\star \star}$ & $(16.64)^{\star \star}$ \\
\hline Technical School & 0.656 & 0.536 & 0.737 \\
\hline (Max. attainment of members) & $(45.80)^{\star \star}$ & $(32.96)^{\star \star}$ & $(23.62)^{\star \star}$ \\
\hline Higher Education & 1.019 & 0.906 & 1.13 \\
\hline (Max. attainment of members) & $(67.16)^{\star \star}$ & $(54.05)^{\star \star}$ & $(25.15)^{\star \star}$ \\
\hline \multirow[t]{2}{*}{ Agricultural Land } & 0.528 & 0.98 & 4.988 \\
\hline & $(1.34)$ & $(2.13)^{\star}$ & $(5.45)^{\star \star}$ \\
\hline \multirow[t]{2}{*}{ [Agricultural land] $^{2}$} & 0.406 & -0.144 & -23.074 \\
\hline & $(0.53)$ & $(0.18)$ & $(3.31)^{\star \star}$ \\
\hline \multirow[t]{2}{*}{ Sylvicultural land } & -2.924 & -2.037 & 0.534 \\
\hline & $(5.12)^{\star \star}$ & $(1.20)$ & $(0.94)$ \\
\hline \multirow[t]{2}{*}{ [Sylvicultural land] $^{2}$} & 6.686 & 13.449 & -2.106 \\
\hline & $(2.91)^{\star \star}$ & $(0.76)$ & $(1.02)$ \\
\hline \multirow[t]{2}{*}{ Aquacultural water } & 9.589 & 5.71 & 5.175 \\
\hline & $(4.68)^{\star \star}$ & $(2.15)^{\star}$ & $(0.53)$ \\
\hline \multirow[t]{2}{*}{ [Aquacultural water]2 } & -28.896 & 78.159 & -7.22 \\
\hline & $(0.76)$ & $(1.18)$ & $(0.09)$ \\
\hline \multirow[t]{2}{*}{ Unused land } & 3.084 & 14.25 & -25.202 \\
\hline & $(0.74)$ & $(2.56)^{\star}$ & $(2.17)^{\star}$ \\
\hline \multirow[t]{2}{*}{ [Unused land]2 } & 1.286 & -120.715 & $1,433.06$ \\
\hline & $(0.02)$ & $(1.68)$ & $(2.29)^{\star}$ \\
\hline Buddhist & 0.06 & 0.04 & 0.06 \\
\hline
\end{tabular}




\begin{tabular}{|c|c|c|c|}
\hline & $(7.86)^{\star \star}$ & $(4.58)^{\star \star}$ & $(3.41)^{\star \star}$ \\
\hline \multirow[t]{2}{*}{ Catholic } & 0.02 & 0.02 & 0.03 \\
\hline & $(1.49)$ & $(1.60)$ & $(1.23)$ \\
\hline \multirow[t]{2}{*}{ Inland Delta } & 0.03 & 0.02 & 0.24 \\
\hline & $(2.19)^{\star}$ & $(1.64)$ & $(3.27)^{\star \star}$ \\
\hline \multirow[t]{2}{*}{ Low Mountains } & -0.17 & -0.12 & -0.09 \\
\hline & $(12.20)^{\star \star}$ & $(7.89)^{\star \star}$ & (1.34) \\
\hline \multirow[t]{2}{*}{ High Mountains } & -0.30 & -0.04 & -0.18 \\
\hline & $(20.14)^{\star *}$ & $(2.14)^{\star}$ & $(2.56)^{\star}$ \\
\hline \multirow[t]{2}{*}{ Coastal } & 0.092 & 0.075 & 0.45 \\
\hline & $(5.81)^{\star \star}$ & $(4.64)^{\star \star}$ & $(4.50)^{\star \star}$ \\
\hline \multirow[t]{2}{*}{ Constant } & 7.84 & 8.00 & 7.51 \\
\hline & $(319.82)^{\star *}$ & $(295.73)^{* *}$ & (91.71 \\
\hline Observations & 3879 & 3296 & 583 \\
\hline R-squared & 0.49 & 0.43 & 0.24 \\
\hline \multirow{2}{*}{ Joint Significance F Test } & $F(25,3853)$ & $F(25,3270)$ & $F(25,557)$ \\
\hline & $=145.88^{* *}$ & $=99.16^{\star \star}$ & $=7.10^{* *}$ \\
\hline Prob. $>\mathrm{F}$ & 0.0000 & 0.0000 & 0.0000 \\
\hline
\end{tabular}

${ }^{*}$ significant at $5 \%$; ${ }^{* *}$ significant at $1 \%$, Significant coefficients are shown in bold. 
Table 8 - Determinants of log of per capita Consumption by Ethnic Group in 2004 (with Commune Fixed Effects)

\begin{tabular}{|c|c|c|c|c|c|c|c|c|c|c|}
\hline & Total & Majority & Kinh & Minority & Tay & Thai & Khmer & Muong & Nung & Dao \\
\hline & $\begin{array}{l}\text { Coef. } \\
\text { (t value) }\end{array}$ & $\begin{array}{l}\text { Coef. } \\
\text { (t value) }\end{array}$ & $\begin{array}{l}\text { Coef. } \\
\text { (t value) }\end{array}$ & $\begin{array}{l}\text { Coef. } \\
\text { (t value) }\end{array}$ & $\begin{array}{l}\text { Coef. } \\
\text { (t value) }\end{array}$ & $\begin{array}{l}\text { Coef. } \\
\text { (t value) }\end{array}$ & $\begin{array}{l}\text { Coef. } \\
\text { (t value) }\end{array}$ & $\begin{array}{l}\text { Coef. } \\
\text { (t value) }\end{array}$ & $\begin{array}{l}\text { Coef. } \\
\text { (t value) }\end{array}$ & $\begin{array}{l}\text { Coef. } \\
\text { (t value) }\end{array}$ \\
\hline Age of Household head & $\begin{array}{l}0 \\
(1.05)\end{array}$ & $\begin{array}{l}0 \\
(1.07)\end{array}$ & $\begin{array}{l}0 \\
(1.04)\end{array}$ & $\begin{array}{l}-0.002 \\
(1.63)\end{array}$ & $\begin{array}{l}-0.007 \\
(2.96)^{\star \star}\end{array}$ & $\begin{array}{l}-0.004 \\
(1.26)\end{array}$ & $\begin{array}{l}-0.006 \\
(1.07)\end{array}$ & $\begin{array}{l}-0.002 \\
(0.54)\end{array}$ & $\begin{array}{l}0 \\
(0.09)\end{array}$ & $\begin{array}{l}-0.002 \\
(0.42)\end{array}$ \\
\hline $\begin{array}{l}\text { The Share of Female } \\
\text { Members }\end{array}$ & $\begin{array}{l}-0.012 \\
(0.43)\end{array}$ & $\begin{array}{l}-0.023 \\
(0.71)\end{array}$ & $\begin{array}{l}-0.019 \\
(0.58)\end{array}$ & $\begin{array}{l}-0.024 \\
(0.31)\end{array}$ & $\begin{array}{l}-0.143 \\
(0.97)\end{array}$ & $\begin{array}{l}-0.143 \\
(0.66)\end{array}$ & $\begin{array}{l}0.125 \\
(0.45)\end{array}$ & $\begin{array}{l}-0.054 \\
(0.22)\end{array}$ & $\begin{array}{l}0.193 \\
(0.75)\end{array}$ & $\begin{array}{l}-0.78 \\
(1.81)\end{array}$ \\
\hline Dependency Burden & $\begin{array}{l}-0.294 \\
(13.34)^{\star \star}\end{array}$ & $\begin{array}{l}-0.299 \\
(12.67)^{\star *}\end{array}$ & $\begin{array}{l}-0.301 \\
(12.68)^{\star *}\end{array}$ & $\begin{array}{l}-0.282 \\
(4.07)^{\star \star}\end{array}$ & $\begin{array}{l}-0.356 \\
(2.42)^{\star}\end{array}$ & $\begin{array}{l}-0.021 \\
(0.11)\end{array}$ & $\begin{array}{l}-0.304 \\
(1.24)\end{array}$ & $\begin{array}{l}-0.609 \\
(2.97)^{\star \star}\end{array}$ & $\begin{array}{l}-0.345 \\
(1.28)\end{array}$ & $\begin{array}{l}-0.044 \\
(0.15)\end{array}$ \\
\hline $\begin{array}{l}\text { Whether a household head } \\
\text { is married }\end{array}$ & $\begin{array}{l}0.049 \\
(3.16)^{\star \star}\end{array}$ & $\begin{array}{l}0.055 \\
(3.29)^{\star \star}\end{array}$ & $\begin{array}{l}0.057 \\
(3.42)^{\star \star}\end{array}$ & $\begin{array}{l}0.011 \\
(0.22)\end{array}$ & $\begin{array}{l}-0.036 \\
(0.37)\end{array}$ & $\begin{array}{l}0.122 \\
(0.77)\end{array}$ & $\begin{array}{l}0.133 \\
(0.81)\end{array}$ & $\begin{array}{l}0.283 \\
(1.79)\end{array}$ & $\begin{array}{l}-0.108 \\
(0.48)\end{array}$ & $\begin{array}{l}-0.315 \\
(2.20)^{\star}\end{array}$ \\
\hline $\begin{array}{l}\text { Primary School } \\
\text { (Max. attainment of } \\
\text { members) }\end{array}$ & $\begin{array}{l}0.003 \\
(0.14)\end{array}$ & $\begin{array}{l}-0.039 \\
(1.49)\end{array}$ & $\begin{array}{l}-0.037 \\
(1.42)\end{array}$ & $\begin{array}{l}0.054 \\
(1.40)\end{array}$ & $\begin{array}{l}0.01 \\
(0.08)\end{array}$ & $\begin{array}{l}0.133 \\
(1.33)\end{array}$ & $\begin{array}{l}0.256 \\
(1.36)\end{array}$ & $\begin{array}{l}0.01 \\
(0.04)\end{array}$ & $\begin{array}{l}-0.08 \\
(0.39)\end{array}$ & $\begin{array}{l}0.234 \\
(2.06)\end{array}$ \\
\hline $\begin{array}{l}\text { Lower Secondary School } \\
\text { (Max. attainment of } \\
\text { members) }\end{array}$ & $\begin{array}{l}0.068 \\
(3.08)^{\star \star}\end{array}$ & $\begin{array}{l}0.019 \\
(0.74)\end{array}$ & $\begin{array}{l}0.017 \\
(0.64)\end{array}$ & $\begin{array}{l}0.15 \\
(3.41)^{\star \star}\end{array}$ & $\begin{array}{l}0.119 \\
(1.05)\end{array}$ & $\begin{array}{l}0.252 \\
(2.27)^{\star}\end{array}$ & $\begin{array}{l}0.268 \\
(1.26)\end{array}$ & $\begin{array}{l}0.127 \\
(0.52)\end{array}$ & $\begin{array}{l}0.07 \\
(0.35)\end{array}$ & $\begin{array}{l}0.28 \\
(1.85)\end{array}$ \\
\hline $\begin{array}{l}\text { Upper Secondary School } \\
\text { (Max. attainment of } \\
\text { members) }\end{array}$ & $\begin{array}{l}0.202 \\
(8.61)^{\star \star}\end{array}$ & $\begin{array}{l}0.151 \\
(5.53)^{\star \star}\end{array}$ & $\begin{array}{l}0.151 \\
(5.50)^{\star \star}\end{array}$ & $\begin{array}{l}0.27 \\
(4.87)^{\star \star}\end{array}$ & $\begin{array}{l}0.301 \\
(2.49)^{\star}\end{array}$ & $\begin{array}{l}0.266 \\
(1.39)\end{array}$ & $\begin{array}{l}0.046 \\
(0.19)\end{array}$ & $\begin{array}{l}0.284 \\
(1.07)\end{array}$ & $\begin{array}{l}0.08 \\
(0.36)\end{array}$ & $\begin{array}{l}0.129 \\
(0.63)\end{array}$ \\
\hline Higher Education & 0.443 & 0.399 & 0.398 & 0.41 & 0.197 & 0.914 & -0.126 & 0.647 & 0.48 & 0 \\
\hline $\begin{array}{l}\text { (Max. attainment of } \\
\text { members) }\end{array}$ & $(15.26)^{\star \star}$ & $(12.36)^{\star \star}$ & $(12.27)^{\star \star}$ & $(4.16)^{\star \star}$ & (1.09) & $(1.87)$ & $(0.29)$ & $(1.92)$ & $(1.14)$ & (.) \\
\hline
\end{tabular}




\begin{tabular}{|c|c|c|c|c|c|c|c|c|c|c|}
\hline Land & $\begin{array}{l}5.609 \\
(7.56)^{\star \star}\end{array}$ & $\begin{array}{l}6.187 \\
(5.86)^{\star \star}\end{array}$ & $\begin{array}{l}6.26 \\
(5.90)^{\star \star}\end{array}$ & $\begin{array}{l}5.235 \\
(3.91)^{\star \star}\end{array}$ & $\begin{array}{l}2.282 \\
(1.08)\end{array}$ & $\begin{array}{l}-1.771 \\
(0.15)\end{array}$ & $\begin{array}{l}28.518 \\
(1.44)\end{array}$ & $\begin{array}{l}5.686 \\
(1.09)\end{array}$ & $\begin{array}{l}-2.659 \\
(0.20)\end{array}$ & $\begin{array}{l}-6.931 \\
(0.68)\end{array}$ \\
\hline Land2 & $\begin{array}{l}-16.909 \\
(5.60)^{\star \star}\end{array}$ & $\begin{array}{l}-19.969 \\
(2.54)^{\star}\end{array}$ & $\begin{array}{l}-20.405 \\
(2.59)^{\star \star}\end{array}$ & $\begin{array}{l}-15.644 \\
(3.70)^{\star \star}\end{array}$ & $\begin{array}{l}-6.57 \\
(1.01)\end{array}$ & $\begin{array}{l}168.357 \\
(0.67)\end{array}$ & $\begin{array}{l}-113.825 \\
(0.18)\end{array}$ & $\begin{array}{l}-16.569 \\
(1.10)\end{array}$ & $\begin{array}{l}100.549 \\
(0.37)\end{array}$ & $\begin{array}{l}171.645 \\
(1.42)\end{array}$ \\
\hline Constant & $\begin{array}{l}8.093 \\
(202.10)\end{array}$ & $\begin{array}{l}8.217 \\
(177.64)\end{array}$ & $\begin{array}{l}8.212 \\
(176.79)\end{array}$ & $\begin{array}{l}7.707 \\
(80.98)\end{array}$ & $\begin{array}{l}8.175 \\
(39.69)\end{array}$ & $\begin{array}{l}7.522 \\
(25.55)\end{array}$ & $\begin{array}{l}7.846 \\
(21.93)\end{array}$ & $\begin{array}{l}7.578 \\
(24.70)\end{array}$ & $\begin{array}{l}7.909 \\
(17.98)\end{array}$ & $\begin{array}{l}8.264 \\
(19.13)\end{array}$ \\
\hline Observations & 8642 & 7330 & 7283 & 1312 & 291 & 186 & 73 & 131 & 83 & 55 \\
\hline R-squared & 0.14 & 0.14 & 0.14 & 0.12 & 0.17 & 0.12 & 0.49 & 0.3 & 0.18 & 0.52 \\
\hline Joint Significance F Test & $\begin{array}{l}F(10,5630) \\
=91.62^{* *}\end{array}$ & $\begin{array}{l}F(10,4675) \\
=78.09^{\star \star}\end{array}$ & $\begin{array}{l}F(10,4635) \\
=77.59^{* *}\end{array}$ & $\begin{array}{l}F(10, \\
758) \\
=10.44^{* *}\end{array}$ & $\begin{array}{l}F(10,184) \\
=3.77^{\star \star}\end{array}$ & $\begin{array}{l}F(10,114) \\
=1.47\end{array}$ & $\begin{array}{l}F(10,35) \\
=3.41^{\star *}\end{array}$ & $\begin{array}{l}F(10,77) \\
=3.24^{\star *}\end{array}$ & $\begin{array}{l}F(10,45) \\
=0.96\end{array}$ & $\begin{array}{l}F(9,18) \\
=2.14\end{array}$ \\
\hline Prob. $>\mathrm{F}$ & 0.0000 & 0.0000 & 0.0000 & 0.0000 & 0.0001 & 0.1520 & 0.0033 & 0.0016 & 0.4938 & 0.0814 \\
\hline Number of Communes & 2996 & 2645 & 2638 & 544 & 97 & 62 & 28 & 44 & 28 & 28 \\
\hline
\end{tabular}

* significant at $5 \%$; ${ }^{* *}$ significant at $1 \%$, Significant coefficients are shown in bold. 
Table 8 - Determinants of log of per capita consumption by Ethnic Group in 2004 (with Commune Fixed Effects) (cont.)

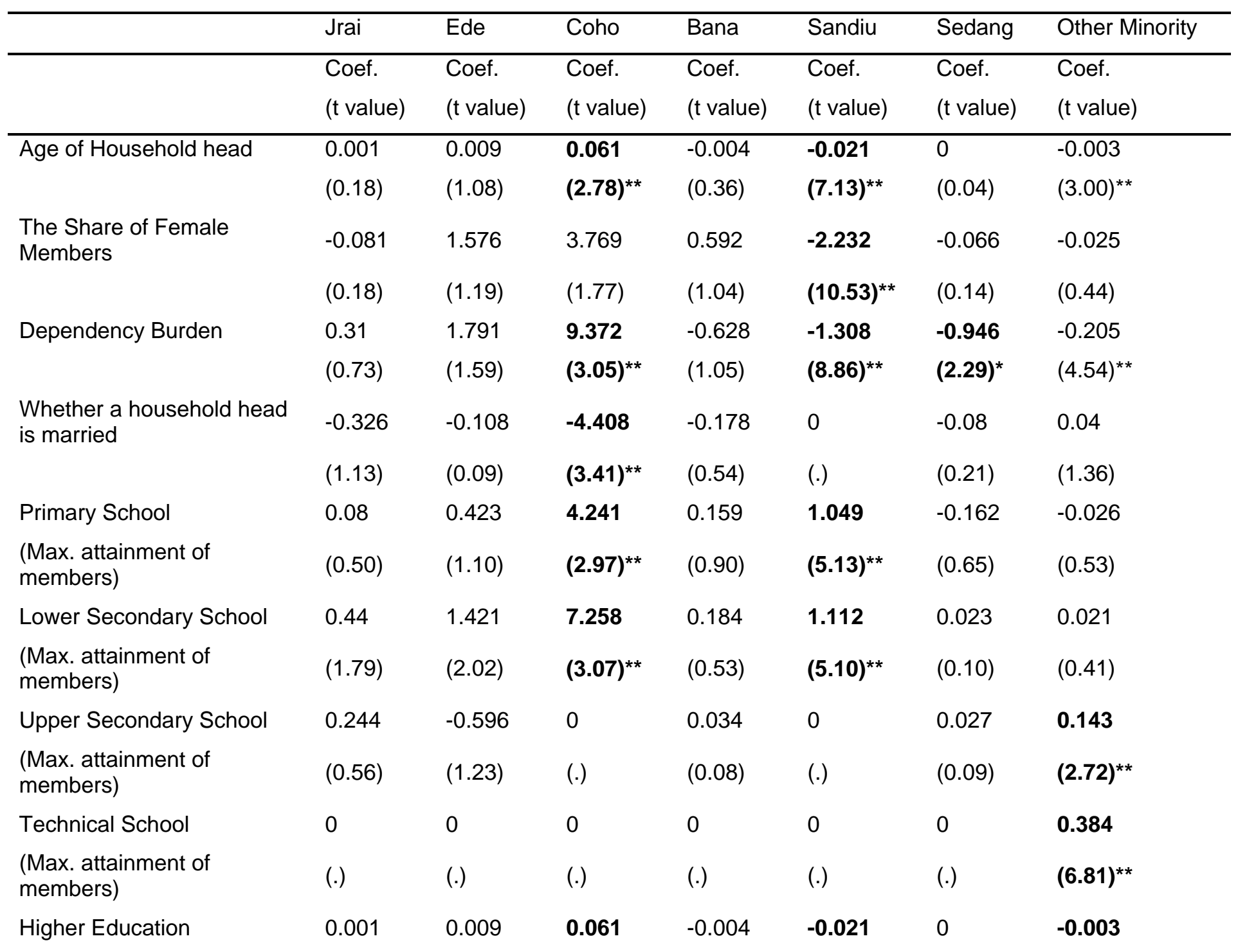




\begin{tabular}{|c|c|c|c|c|c|c|c|}
\hline $\begin{array}{l}\text { (Max. attainment of } \\
\text { members) }\end{array}$ & $(0.18)$ & $(1.08)$ & $(2.78)^{\star \star}$ & $(0.36)$ & $(7.13)^{\star \star}$ & $(0.04)$ & $(3.00)^{\star \star}$ \\
\hline \multirow[t]{2}{*}{ Land } & 42.312 & -12.422 & -346.316 & 8.659 & 296.497 & 50.148 & 6.425 \\
\hline & $(1.56)$ & $(0.48)$ & $(2.96)^{\star \star}$ & $(0.14)$ & $(8.17)^{\star *}$ & $(2.48)^{*}$ & $(2.97)^{\star \star}$ \\
\hline \multirow[t]{2}{*}{ Land2 } & -327.122 & 40.534 & $3,923.33$ & -395.719 & $-12,452.69$ & -626.843 & -20.929 \\
\hline & $(1.00)$ & $(0.20)$ & $(2.78)^{\star \star}$ & $(0.22)$ & $(4.88)^{\star \star}$ & $(2.20)^{\star}$ & $(1.21)$ \\
\hline \multirow[t]{2}{*}{ Constant } & 6.83 & 5.38 & 3.822 & 7.602 & 8.27 & 7.583 & 8.479 \\
\hline & $(11.64)$ & $(2.43)$ & $(1.86)$ & $(8.06)$ & $(38.86)$ & $(15.11)$ & $(103.58)$ \\
\hline Observations & 34 & 24 & 17 & 26 & 17 & 27 & 2447 \\
\hline R-squared & 0.71 & 0.85 & 0.97 & 0.42 & 1 & 0.83 & 0.13 \\
\hline \multirow{2}{*}{ Joint Significance F Test } & $F(9,12)$ & $F(9,4)$ & $F(8,1)$ & $F(9,7)$ & $\mathrm{F}(7,1)$ & $F(9,6)$ & $F(10,1554)$ \\
\hline & $=3.19^{\star}$ & $=2.54$ & $=3.54$ & $=0.56$ & $=2.40$ & $=3.14$ & $=22.37^{\star \star}$ \\
\hline Prob. $>\mathrm{F}$ & 0.0323 & 0.1913 & 0.3903 & 0.7950 & 0.0759 & 0.0884 & 0.0000 \\
\hline Number of Communes & 13 & 11 & 8 & 10 & 9 & 12 & 883 \\
\hline
\end{tabular}


Table 9 - Determinants of log of per capita consumption by Ethnic Group in 2004

(Without Commune Fixed Effects, with Regional Dummies)

\begin{tabular}{|c|c|c|c|}
\hline & Total & Majority & Minority \\
\hline & $\begin{array}{l}\text { Coef. } \\
\text { (t value) }\end{array}$ & $\begin{array}{l}\text { Coef. } \\
\text { (t value) }\end{array}$ & $\begin{array}{l}\text { Coef. } \\
\text { (t value) }\end{array}$ \\
\hline Age of Household head & $\begin{array}{l}0.001 \\
(2.48)^{\star}\end{array}$ & $\begin{array}{l}0.001 \\
(1.67)\end{array}$ & $\begin{array}{l}-0.001 \\
(1.01)\end{array}$ \\
\hline $\begin{array}{l}\text { The Share of Female } \\
\text { Members }\end{array}$ & $\begin{array}{l}0.073 \\
(2.23)^{\star}\end{array}$ & $\begin{array}{l}0.04 \\
(1.13)\end{array}$ & $\begin{array}{l}0.129 \\
(1.72)\end{array}$ \\
\hline Dependency Burden & $\begin{array}{l}-0.349 \\
(14.76)^{\star \star}\end{array}$ & $\begin{array}{l}-0.378 \\
(15.14)^{\star \star}\end{array}$ & $\begin{array}{l}-0.263 \\
(4.17)^{\star \star}\end{array}$ \\
\hline $\begin{array}{l}\text { Whether a household head } \\
\text { is married }\end{array}$ & $\begin{array}{l}0.03 \\
(1.74)\end{array}$ & $\begin{array}{l}0.052 \\
(2.83)^{\star \star}\end{array}$ & $\begin{array}{l}0.037 \\
(0.80)\end{array}$ \\
\hline $\begin{array}{l}\text { Primary School } \\
\text { (Max. attainment of } \\
\text { members) }\end{array}$ & $\begin{array}{l}0.083 \\
(3.80)^{\star \star}\end{array}$ & $\begin{array}{l}-0.02 \\
(0.74)\end{array}$ & $\begin{array}{l}0.147 \\
(4.21)^{\star \star}\end{array}$ \\
\hline $\begin{array}{l}\text { Lower Secondary School } \\
\text { (Max. attainment of } \\
\text { members) }\end{array}$ & $\begin{array}{l}0.144 \\
(6.78)^{\star \star}\end{array}$ & $\begin{array}{l}0 \\
(0.02)\end{array}$ & $\begin{array}{l}0.282 \\
(7.66)^{\star \star}\end{array}$ \\
\hline $\begin{array}{l}\text { Upper Secondary School } \\
\text { (Max. attainment of } \\
\text { members) }\end{array}$ & $\begin{array}{l}0.328 \\
(14.44)^{\star \star}\end{array}$ & $\begin{array}{l}0.175 \\
(6.45)^{\star *}\end{array}$ & $\begin{array}{l}0.5 \\
(10.78)^{\star \star}\end{array}$ \\
\hline $\begin{array}{l}\text { Higher Education } \\
\text { (Max. attainment of } \\
\text { members) }\end{array}$ & $\begin{array}{l}0.644 \\
(18.99)^{\star *}\end{array}$ & $\begin{array}{l}0.517 \\
(13.96)^{\star \star}\end{array}$ & $\begin{array}{l}0.626 \\
(6.19)^{\star \star}\end{array}$ \\
\hline Land & $\begin{array}{l}4.68 \\
(7.66)^{\star \star}\end{array}$ & $\begin{array}{l}6.835 \\
(8.81)^{\star \star}\end{array}$ & $\begin{array}{l}4.251 \\
(4.47)^{\star \star}\end{array}$ \\
\hline Land2 & $\begin{array}{l}-14.151 \\
(5.51)^{\star \star}\end{array}$ & $\begin{array}{l}-23.493 \\
(5.70)^{\star \star}\end{array}$ & $\begin{array}{l}-11.28 \\
(3.34)^{\star \star}\end{array}$ \\
\hline Buddhist & $\begin{array}{l}(0.09) \\
(6.87)^{\star \star}\end{array}$ & $\begin{array}{l}(0.04) \\
(3.30)^{\star \star}\end{array}$ & $\begin{array}{l}(0.09) \\
(1.96)\end{array}$ \\
\hline Catholic & $\begin{array}{l}(0.13) \\
(6.88)^{\star \star}\end{array}$ & $\begin{array}{l}(0.07) \\
(3.33)^{\star \star}\end{array}$ & $\begin{array}{l}(0.10) \\
(2.48)^{\star}\end{array}$ \\
\hline Inland Delta & $\begin{array}{l}-0.04 \\
(1.69)\end{array}$ & $\begin{array}{l}-0.04 \\
(1.85)\end{array}$ & $\begin{array}{l}-0.04 \\
(0.37)\end{array}$ \\
\hline Low Mountains & $\begin{array}{l}-0.15 \\
(5.78)^{\star \star}\end{array}$ & $\begin{array}{l}-0.09 \\
(3.33)^{\star \star}\end{array}$ & $\begin{array}{l}-0.12 \\
(1.19)\end{array}$ \\
\hline High Mountains & $\begin{array}{l}-0.29 \\
(11.08)^{\star \star}\end{array}$ & $\begin{array}{l}0.02 \\
(0.54)\end{array}$ & $\begin{array}{l}-0.20 \\
(2.04)^{\star}\end{array}$ \\
\hline
\end{tabular}




\begin{tabular}{llll} 
Coastal & $\mathbf{( 0 . 0 7 )}$ & $\mathbf{( 0 . 0 8 )}$ & $(0.14)$ \\
& $\left(\mathbf{2 . 2 4 ) ^ { * }}\right.$ & $\left(\mathbf{2 . 6 1 ) ^ { \star * }}\right.$ & $(0.90)$ \\
Constant & 7.86 & 8.03 & 7.59 \\
& 164.67 & 150.59 & 57.57 \\
\hline Observations & 6473 & 5304 & 1169 \\
R-squared & 0.21 & 0.16 & 0.22 \\
Joint Significance F Test & $\mathrm{F}(16,6456)$ & $\mathrm{F}(16,5287)$ & $\mathrm{F}(16,1152)$ \\
Prob. $>\mathrm{F}$ & $=105.86^{* *}$ & $=61.41^{\star *}$ & $=20.22^{* *}$ \\
& 0.0000 & 0.0000 & 0.0000 \\
\hline
\end{tabular}

significant at $5 \% ;{ }^{* *}$ significant at $1 \%$, Significant coefficients are shown in bold.

The coefficient of the dummy variable 'whether a household head is married' has a significant and positive (expected) sign for the ethnic majorities, but it is not significant for the ethnic minorities. As disaggregated data on land are not available for 2004 , the total land area and its square are used. As expected, the former is positive and the latter negative. This implies that per capita household consumption increases as does land area, but there is a non-linear effect, that is, the positive marginal effect of land gets smaller as land area increases. ${ }^{11}$ In Table 9 with regional and religion dummies, we observe positive and significant coefficients for the Buddhists and Catholics, and for those inhabiting Coastal Area. These results are used for the decompositions.

The poverty regression results are given in Tables 10,11, 12 and 13. Table 10 shows the results for 2002 of the conditional fixed-effects logistic model with commune fixed effects. The results based on a probit model with regional dummy variables but without commune effects, for 2002, are given in Table 11. Tables 12 and 13, based on the data for 2004, correspond to Tables 10 and Table 11 for 2002, respectively. For each case, three sets of poverty cut-off points, $100 \%, 80 \%$ and $120 \%$ of the poverty line, are used to test the sensitivity of the results. Because we focus on poverty, rather than consumption, the signs of most of the coefficient estimates are simply the opposite of those in the expenditure function. A summary of the key findings is given below.

We note from Table 10 that significant determinants of poverty are: (i) age of household head (negative, only for ethnic majorities and not for minorities), (ii) dependency burden (both for majorities and minorities), (iii) whether a household head is married (negative (for $80 \%$ of the poverty line) for majorities; positive for minorities), (iv) most of the education variables (negative), and ( $v$ ) most of the categories of level of land (negative). The results in Table 11 are not different from those in Table 10 and the signs of the coefficients are the opposite of those in

\footnotetext{
${ }^{11}$ Similar results are obtained for the 2002 data if the sub-categories of land are aggregated. We use disaggregated data on land for 2002 in order to facilitate comparison of our results with those reported by van de Walle and Gunewardena (2001).
} 
Table 7. For example, being a Buddhist has a negative association with poverty, while living in mountain areas is associated with higher poverty. Note that the comparison group is 'Hills' when we obtain positive and significant coefficient estimates for 'High mountains' and 'Low mountains' in poverty equations.

Tables 12 and 13 report the results of poverty regressions for 2004. Most of the results are expected in light of the earlier results for expenditure. The coefficients of dependency burden are positive and significant; those for a married household head are positive and significant only for the majority; those for higher levels of education are negative and significant; those of land are negative and significant, while those of its square are positive and significant; and those of living in mountain areas are positive and significant. 
Table 10 - Determinants of Poverty in Total Sample, and among Ethnic Majority and Ethnic Minority in 2002

(Conditional fixed-effects logistic regression, with Commune Fixed Effects)

\begin{tabular}{|c|c|c|c|c|c|c|c|c|c|}
\hline & $\begin{array}{l}\text { Poverty100 } \\
\text { Total }\end{array}$ & $\begin{array}{l}\text { Poverty80 } \\
\text { Total }\end{array}$ & $\begin{array}{l}\text { Poverty120 } \\
\text { Total }\end{array}$ & $\begin{array}{l}\text { Poverty100 } \\
\text { Majority }\end{array}$ & $\begin{array}{l}\text { Poverty80 } \\
\text { Majority }\end{array}$ & $\begin{array}{l}\text { Poverty120 } \\
\text { Minority }\end{array}$ & $\begin{array}{l}\text { Poverty100 } \\
\text { Minority }\end{array}$ & $\begin{array}{l}\text { Poverty80 } \\
\text { Minority }\end{array}$ & $\begin{array}{l}\text { Poverty120 } \\
\text { Minority }\end{array}$ \\
\hline & $\begin{array}{l}\text { Coef. } \\
\text { (z value) }\end{array}$ & $\begin{array}{l}\text { Coef. } \\
\text { (z value) }\end{array}$ & $\begin{array}{l}\text { Coef. } \\
\text { (z value) }\end{array}$ & $\begin{array}{l}\text { Coef. } \\
\text { (z value) }\end{array}$ & $\begin{array}{l}\text { Coef. } \\
\text { (z value) }\end{array}$ & $\begin{array}{l}\text { Coef. } \\
\text { (z value) }\end{array}$ & $\begin{array}{l}\text { Coef. } \\
\text { (z value) }\end{array}$ & $\begin{array}{l}\text { Coef. } \\
\text { (z value) }\end{array}$ & $\begin{array}{l}\text { Coef. } \\
\text { (z value) }\end{array}$ \\
\hline Age of Household head & $\begin{array}{l}-0.008 \\
(5.70)^{\star \star}\end{array}$ & $\begin{array}{l}-0.01 \\
(6.08)^{\star \star}\end{array}$ & $\begin{array}{l}-0.008 \\
(6.12)^{\star \star}\end{array}$ & $\begin{array}{l}-0.008 \\
(5.58)^{\star \star}\end{array}$ & $\begin{array}{l}-0.011 \\
(5.68)^{\star \star}\end{array}$ & $\begin{array}{c}-0.008 \\
(5.75)^{\star \star}\end{array}$ & $\begin{array}{l}0.003 \\
(0.67)\end{array}$ & $\begin{array}{l}0.001 \\
(0.22)\end{array}$ & $\begin{array}{l}-0.002 \\
(0.41)\end{array}$ \\
\hline $\begin{array}{l}\text { The Share of Female } \\
\text { Members }\end{array}$ & $\begin{array}{l}0.109 \\
(1.17)\end{array}$ & $\begin{array}{l}0.221 \\
(1.97)^{\star}\end{array}$ & $\begin{array}{l}0.111 \\
(1.29)\end{array}$ & $\begin{array}{l}0.085 \\
(0.86)\end{array}$ & $\begin{array}{l}0.18 \\
(1.42)\end{array}$ & $\begin{array}{l}0.136 \\
(1.49)\end{array}$ & $\begin{array}{l}0.251 \\
(0.89)\end{array}$ & $\begin{array}{l}0.469 \\
(1.74)\end{array}$ & $\begin{array}{l}-0.142 \\
(0.46)\end{array}$ \\
\hline Dependency Burden & $\begin{array}{l}1.726 \\
(21.86)^{\star \star}\end{array}$ & $\begin{array}{l}1.717 \\
(17.46)^{\star \star}\end{array}$ & $\begin{array}{l}1.57 \\
(21.77)^{\star \star}\end{array}$ & $\begin{array}{l}1.703 \\
(20.08)^{\star *}\end{array}$ & $\begin{array}{l}1.634 \\
(14.78)^{\star *}\end{array}$ & $\begin{array}{l}1.552 \\
(20.45)^{\star \star}\end{array}$ & $\begin{array}{l}2.069 \\
(7.98)^{\star \star}\end{array}$ & $\begin{array}{l}2.262 \\
(9.00)^{\star *}\end{array}$ & $\begin{array}{l}2.024 \\
(7.24)^{\star \star}\end{array}$ \\
\hline $\begin{array}{l}\text { Whether a household head is } \\
\text { married }\end{array}$ & $\begin{array}{l}-0.008 \\
(0.14)\end{array}$ & $\begin{array}{l}-0.084 \\
(1.26)\end{array}$ & $\begin{array}{l}0.027 \\
(0.56)\end{array}$ & $\begin{array}{l}-0.095 \\
(1.65)\end{array}$ & $\begin{array}{l}-0.186 \\
(2.52)^{\star}\end{array}$ & $\begin{array}{l}-0.013 \\
(0.24)\end{array}$ & $\begin{array}{l}0.627 \\
(3.75)^{\star \star}\end{array}$ & $\begin{array}{l}0.442 \\
(2.66)^{\star \star}\end{array}$ & $\begin{array}{l}0.447 \\
(2.52)^{\star}\end{array}$ \\
\hline $\begin{array}{l}\text { Primary School } \\
\text { (Max. attainment of } \\
\text { members) }\end{array}$ & $\begin{array}{l}0.061 \\
(0.96)\end{array}$ & $\begin{array}{l}0.011 \\
(0.16)\end{array}$ & $\begin{array}{l}0.095 \\
(1.56)\end{array}$ & $\begin{array}{l}0.198 \\
(2.76)^{\star \star}\end{array}$ & $\begin{array}{l}0.164 \\
(1.85)\end{array}$ & $\begin{array}{l}0.234 \\
(3.50)^{\star \star}\end{array}$ & $\begin{array}{l}-0.253 \\
(1.64)\end{array}$ & $\begin{array}{l}-0.173 \\
(1.28)\end{array}$ & $\begin{array}{l}-0.474 \\
(2.55)^{\star}\end{array}$ \\
\hline $\begin{array}{l}\text { Lower Secondary School } \\
\text { (Max. attainment of } \\
\text { members) }\end{array}$ & $\begin{array}{l}-0.365 \\
(5.44)^{\star \star}\end{array}$ & $\begin{array}{l}-0.552 \\
(7.07)^{\star \star}\end{array}$ & $\begin{array}{l}-0.305 \\
(4.77)^{\star \star}\end{array}$ & $\begin{array}{l}-0.172 \\
(2.28)^{\star}\end{array}$ & $\begin{array}{l}-0.335 \\
(3.55)^{\star \star}\end{array}$ & $\begin{array}{l}-0.126 \\
(1.81)\end{array}$ & $\begin{array}{l}-0.786 \\
(4.43)^{\star \star}\end{array}$ & $\begin{array}{l}-0.796 \\
(4.92)^{\star \star}\end{array}$ & $\begin{array}{l}-1 \\
(4.80)^{\star \star}\end{array}$ \\
\hline $\begin{array}{l}\text { Upper Secondary School } \\
\text { (Max. attainment of } \\
\text { members) }\end{array}$ & $\begin{array}{l}-1.029 \\
(12.92)^{\star \star}\end{array}$ & $\begin{array}{l}-1.223 \\
(12.32)^{\star \star}\end{array}$ & $\begin{array}{l}-0.992 \\
(13.53)^{\star \star}\end{array}$ & $\begin{array}{l}-0.849 \\
(9.60)^{\star \star}\end{array}$ & $\begin{array}{l}-1.035 \\
(8.85)^{\star \star}\end{array}$ & $\begin{array}{l}-0.828 \\
(10.48)^{\star \star}\end{array}$ & $\begin{array}{l}-1.509 \\
(6.77)^{\star \star}\end{array}$ & $\begin{array}{l}-1.374 \\
(6.22)^{\star \star}\end{array}$ & $\begin{array}{l}-1.589 \\
(6.37)^{\star \star}\end{array}$ \\
\hline Technical School & -1.868 & -2.025 & -1.791 & -1.852 & -1.994 & -1.682 & -1.723 & -1.863 & -2.149 \\
\hline
\end{tabular}




\begin{tabular}{|c|c|c|c|c|c|c|c|c|c|}
\hline $\begin{array}{l}\text { (Max. attainment of } \\
\text { members) }\end{array}$ & $(16.47)^{\star \star}$ & $(12.80)^{\star \star}$ & $(18.74)^{\star \star}$ & $(13.68)^{\star \star}$ & $(9.75)^{\star \star}$ & $(15.79)^{\star \star}$ & $(6.74)^{\star \star}$ & $(6.36)^{\star \star}$ & $(7.97)^{\star \star}$ \\
\hline $\begin{array}{l}\text { (Max. attainment of } \\
\text { members) }\end{array}$ & $(13.79)^{\star \star}$ & $(9.42)^{\star \star}$ & $(17.97)^{\star \star}$ & $(11.90)^{\star \star}$ & $(7.80)^{\star \star}$ & $(15.85)^{\star \star}$ & $(5.45)^{\star \star}$ & $(4.27)^{\star \star}$ & $(6.58)^{\star *}$ \\
\hline \multirow[t]{2}{*}{ Agricultural Land } & -45.5 & -44.075 & -37.337 & -57.76 & -70.893 & -44.957 & -45.165 & -47.301 & -50.232 \\
\hline & $(11.49)^{\star \star}$ & $(8.85)^{\star \star}$ & $(11.34)^{\star \star}$ & $(11.13)^{\star \star}$ & $(8.85)^{\star \star}$ & $(9.71)^{\star \star}$ & $(4.47)^{\star \star}$ & $(4.80)^{\star \star}$ & $(4.21)^{\star *}$ \\
\hline$\left[\right.$ Agricultural land] ${ }^{2}$ & 49.125 & 47.902 & 38.845 & 58.758 & 73.071 & 40.194 & 217.485 & 276.354 & 385.25 \\
\hline \multirow[t]{2}{*}{ Sylvicultural land } & -21.708 & -18.544 & -20.104 & -38.927 & -34.597 & -41.948 & -17.39 & -17.134 & -17.28 \\
\hline & $(4.14)^{\star \star}$ & $(3.51)^{\star \star}$ & $(4.04)^{\star \star}$ & $(3.05)^{\star \star}$ & $(2.23)^{\star}$ & $(3.94)^{\star \star}$ & $(3.03)^{\star \star}$ & $(3.07)^{\star \star}$ & $(2.80)^{\star *}$ \\
\hline \multirow[t]{2}{*}{ [Sylvicultural land] $^{2}$} & 59.46 & 56.578 & 59.555 & 230.356 & 294.45 & 307.445 & 37.408 & 43.336 & 39.013 \\
\hline & $(2.06)^{\star}$ & $(1.97)^{*}$ & $(2.40)^{*}$ & $(1.56)$ & $(1.95($ & $(2.92)^{\star \star}$ & $(1.63)$ & $(1.8)$ & $(1.65)$ \\
\hline [Aquacultural water]2 & (.) & -0.3 & $(0.69)$ & (.) & $(0.26)$ & $(0.42)$ & $(2.16)^{\star}$ & $(5.06)^{\star \star}$ & $(1.18)$ \\
\hline \multirow[t]{2}{*}{ Unused land } & 5.552 & 36.061 & 50.724 & -49.731 & -32.31 & 0.759 & 234.086 & 173.48 & 171.82 \\
\hline & $(0.12)$ & $(0.54)$ & $(1.11)$ & $(0.8)$ & $(0.22)$ & $(0.01)$ & $(1.95)$ & $(1.6)$ & $(1.37)$ \\
\hline \multirow[t]{2}{*}{ [Unused land]2 } & 44.643 & $-3,011.86$ & $-1,935.80$ & $2,078.54$ & $-2,808.22$ & 127.88 & $-13,125.12$ & $-11,270.89$ & $-8,165.57$ \\
\hline & $(0.02)$ & $(0.78)$ & $(1.07)$ & $(0.93)$ & $(0.23)$ & $(0.06)$ & $(1.89)$ & $(1.75)$ & $(1.37)$ \\
\hline Observations & 28806 & 28806 & 28806 & 24836 & 24836 & 24836 & 3970 & 3970 & 3970 \\
\hline \multirow{2}{*}{ Joint Significance F Test } & $\operatorname{LR} \operatorname{Chi}^{2}(17)$ & LR Chi' ${ }^{2}(17)$ & $\operatorname{LR} \operatorname{Chi}^{2}(17)$ & $\operatorname{LR} \operatorname{Chi}^{2}(17)$ & $\begin{array}{l}\text { LR } \\
\text { Chi }^{2}(17)\end{array}$ & $\operatorname{LR} \operatorname{Chi}^{2}(17)$ & $\operatorname{LR} \operatorname{Chi}^{2}(17)$ & $\begin{array}{l}\mathrm{LR} \\
\mathrm{Chi}^{2}(17)\end{array}$ & $\operatorname{LR~Chi}^{2}(17)$ \\
\hline & $=2117.27^{\star *}$ & $=1418.72^{* *}$ & $=2437.97^{* *}$ & $=1800.40^{\star *}$ & $=1093.31^{* *}$ & $=2158.14^{\star *}$ & $=334.40^{* *}$ & $=370.34^{\star *}$ & $=265.66^{* *}$ \\
\hline
\end{tabular}




\begin{tabular}{|c|c|c|c|c|c|c|c|c|c|}
\hline Prob. $>F$ & 0.0000 & 0.0000 & 0.0000 & 0.0000 & 0.0000 & 0.0000 & 0.0000 & 0.0000 & 0.0000 \\
\hline Number of Communes & 1744 & 1245 & 1990 & 1496 & 967 & 1770 & 282 & 299 & 254 \\
\hline
\end{tabular}

${ }^{*}$ significant at $5 \%$; ${ }^{* *}$ significant at $1 \%$, Significant coefficients are shown in bold.

Table 11 - Determinants of Poverty in Total Sample, and among Ethnic Majority and Ethnic Minority in 2002

\section{(Probit Model, with Regional Dummies)}

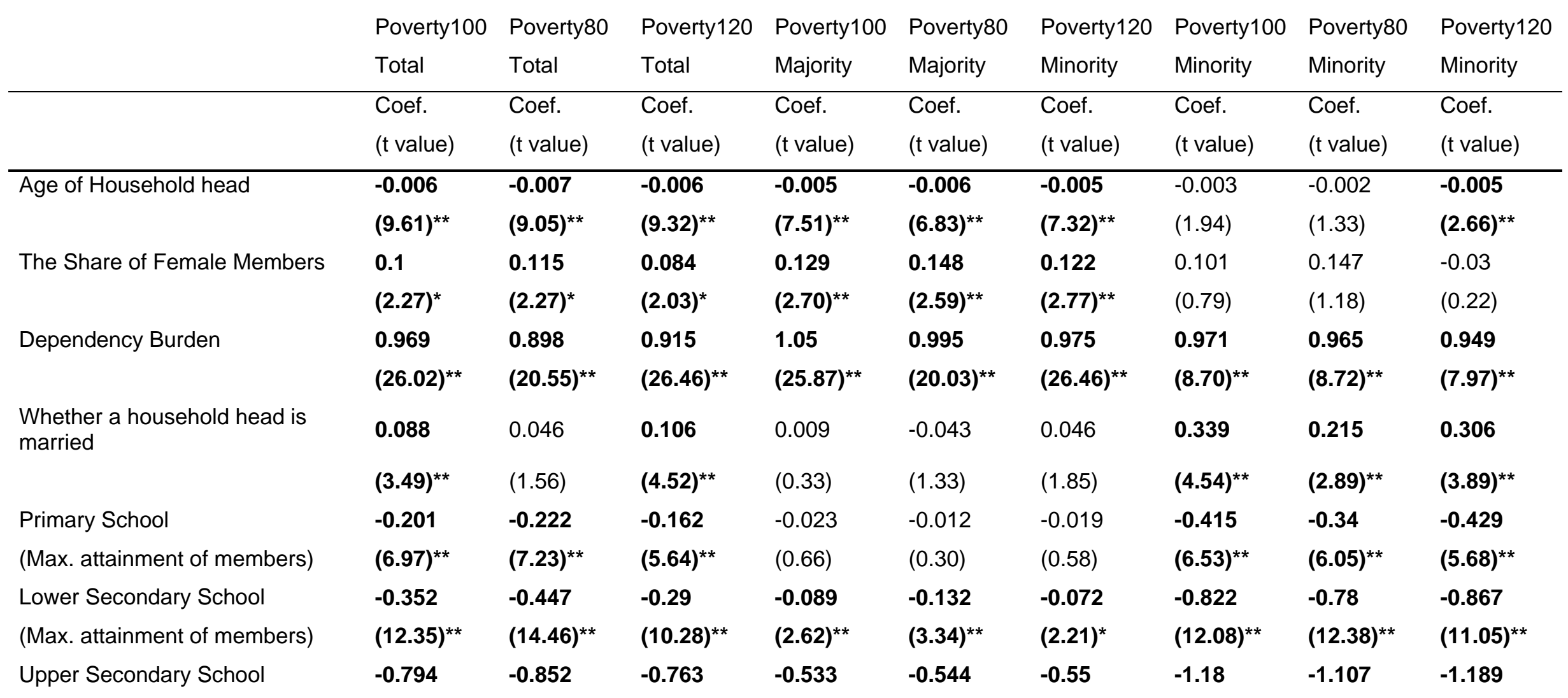




\begin{tabular}{|c|c|c|c|c|c|c|c|c|c|}
\hline (Max. attainment of members) & $(23.52)^{\star \star}$ & $(21.67)^{\star \star}$ & $(23.79)^{\star \star}$ & $(13.63)^{\star \star}$ & $(11.41)^{\star \star}$ & $(15.24)^{\star \star}$ & $(13.29)^{\star \star}$ & $(12.31)^{\star \star}$ & $(12.35)^{\star \star}$ \\
\hline Technical School & -1.402 & -1.43 & -1.354 & -1.142 & -1.121 & -1.103 & -1.677 & -1.621 & -1.845 \\
\hline (Max. attainment of members) & $(29.22)^{\star \star}$ & $(23.01)^{\star \star}$ & $(32.46)^{\star \star}$ & $(20.19)^{\star \star}$ & $(14.40)^{\star \star}$ & $(23.44)^{\star \star}$ & $(15.96)^{\star \star}$ & $(13.92)^{\star \star}$ & $(17.02)^{\star \star}$ \\
\hline Higher Education & -1.951 & -1.825 & -1.937 & -1.698 & -1.54 & -1.709 & -2.252 & -2.026 & -2.348 \\
\hline (Max. attainment of members) & $(24.79)^{\star \star}$ & $(17.26)^{\star *}$ & $(32.14)^{\star \star}$ & $(18.75)^{\star \star}$ & $(12.06)^{\star \star}$ & $(25.64)^{\star \star}$ & $(12.42)^{\star *}$ & $(9.55)^{\star \star}$ & $(14.08)^{\star \star}$ \\
\hline \multirow[t]{2}{*}{ Agricultural Land } & -4.441 & -9.036 & -1.141 & 22.54 & 8.249 & 31.315 & -13.228 & -16.865 & -10.775 \\
\hline & $(2.31)^{\star}$ & $(5.96)^{\star *}$ & $(0.70)$ & $(5.46)^{\star \star}$ & $(1.51)$ & $(9.05)^{\star \star}$ & $(4.24)^{\star \star}$ & $(5.59)^{\star *}$ & $(3.31)^{\star \star}$ \\
\hline \multirow[t]{2}{*}{ 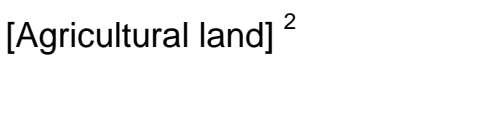 } & -67.059 & 7.813 & -82.245 & $-1,348.38$ & $-1,066.54$ & $-1,355.98$ & 46.497 & 77.151 & 38.325 \\
\hline & $(2.18)^{\star}$ & $(0.83)$ & $(3.81)^{\star \star}$ & $(8.92)^{\star \star}$ & $(4.87)^{\star \star}$ & $(11.98)^{\star *}$ & $(1.78)$ & $(3.27)^{\star *}$ & $(1.49)$ \\
\hline \multirow[t]{2}{*}{ Sylvicultural land } & 5.942 & 3.901 & 6.965 & 4.033 & 8.276 & 2.231 & -2.868 & -5.847 & -2.128 \\
\hline & $(3.80)^{\star \star}$ & $(2.36)^{\star}$ & $(4.39)^{\star \star}$ & $(0.82)$ & $(1.47)$ & $(0.49)$ & $(1.34)$ & $(2.80)^{\star \star}$ & $(0.93)$ \\
\hline \multirow[t]{2}{*}{ 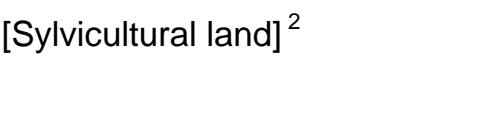 } & -9.944 & -0.788 & -14.52 & -23.531 & -30.151 & -1.696 & 15.614 & 30.395 & 9.766 \\
\hline & $(1.45)$ & $(0.10)$ & $(2.20)^{\star}$ & $(0.44)$ & $(0.51)$ & $(0.04)$ & $(1.48)$ & $(3.03)^{\star \star}$ & $(0.89)$ \\
\hline \multirow[t]{2}{*}{ Aquacultural water } & -13.707 & -4.873 & -15.963 & -8.341 & 5.172 & -12.829 & -59.75 & -42.664 & 31.602 \\
\hline & $(1.69)$ & $(0.31)$ & $(2.53)^{\star}$ & $(0.96)$ & $(0.31)$ & $(1.74)$ & $(1.54)$ & $(1.06)$ & $(0.38)$ \\
\hline \multirow[t]{2}{*}{ [Aquacultural water]2 } & -2.888 & -653.496 & 53.934 & -68.754 & -924.098 & 55.447 & 356.438 & 260.06 & $-2,309.57$ \\
\hline & $(0.01)$ & $(0.91)$ & $(0.36)$ & $(0.28)$ & $(1.15)$ & $(0.28)$ & $(0.75)$ & $(0.61)$ & $(0.59)$ \\
\hline \multirow[t]{2}{*}{ Unused land } & 11.733 & 46.591 & 12.558 & -30.263 & -53.018 & -23.557 & 107.465 & 76.794 & 108.315 \\
\hline & $(0.59)$ & $(1.75)$ & $(0.63)$ & $(1.70)$ & $(1.67)$ & $(1.47)$ & $(2.31)^{\star}$ & $(1.88)$ & $(2.16)^{\star}$ \\
\hline \multirow[t]{2}{*}{ [Unused land]2 } & -877.951 & $-2,936.94$ & $-1,008.52$ & 226.786 & 313.441 & 102.251 & $-6,381.72$ & $-4,665.25$ & $-5,830.95$ \\
\hline & $(0.99)$ & $(1.90)$ & $(1.15)$ & $(0.87)$ & $(0.28)$ & $(0.36)$ & $(2.48)^{*}$ & $(1.98)^{\star}$ & $(2.28)^{\star}$ \\
\hline \multirow[t]{2}{*}{ Buddhist } & -0.136 & -0.118 & -0.145 & -0.084 & -0.082 & -0.082 & 0.169 & 0.211 & 0.075 \\
\hline & $(6.34)^{\star *}$ & $(4.83)^{\star \star}$ & $(7.09)^{\star *}$ & $(3.40)^{\star \star}$ & $(2.78)^{\star *}$ & $(3.61)^{\star \star}$ & $(3.09)^{\star *}$ & $(4.07)^{\star \star}$ & $(1.26)$ \\
\hline Catholic & -0.063 & -0.032 & -0.093 & 0.031 & 0.055 & 0.003 & 0.04 & 0.109 & -0.076 \\
\hline
\end{tabular}




\begin{tabular}{|c|c|c|c|c|c|c|c|c|c|}
\hline & $(2.09)^{*}$ & $(0.94)$ & $(3.18)^{\star \star}$ & $(0.88)$ & $(1.36)$ & $(0.09)$ & $(0.51)$ & $(1.50)$ & $(0.88)$ \\
\hline \multirow[t]{2}{*}{ Inland Delta } & -0.069 & -0.106 & -0.006 & -0.138 & -0.182 & -0.04 & 0.512 & 0.266 & 0.738 \\
\hline & $(1.97)^{\star}$ & $(2.53)^{\star}$ & $(0.19)$ & $(3.32)^{\star \star}$ & $(3.69)^{\star \star}$ & (1.03) & $(1.85)$ & $(0.83)$ & $(2.88)^{\star \star}$ \\
\hline \multirow[t]{2}{*}{ Hills } & - & - & - & -0.089 & -0.111 & -0.047 & 1.057 & 1.133 & 1.166 \\
\hline & - & - & - & $(1.72)$ & $(1.82)$ & $(0.98)$ & $(3.03)^{\star \star}$ & $(2.96)^{\star \star}$ & $(3.46)^{\star \star}$ \\
\hline \multirow[t]{2}{*}{ Low Mountains } & 0.31 & 0.357 & 0.316 & 0.048 & 0.028 & 0.124 & 1.357 & 1.319 & 1.385 \\
\hline & $(7.90)^{\star \star}$ & $(7.82)^{\star \star}$ & $(8.53)^{\star \star}$ & $(1.03)$ & $(0.51)$ & $(2.85)^{\star \star}$ & $(4.99)^{\star \star}$ & $(4.19)^{\star \star}$ & $(5.48)^{\star \star}$ \\
\hline \multirow[t]{2}{*}{ High Mountains } & 0.703 & 0.759 & 0.629 & - & - & - & 1.589 & 1.488 & 1.607 \\
\hline & $(17.10)^{\star \star}$ & $(16.26)^{\star \star}$ & $(15.97)^{\star \star}$ & - & - & - & $(5.86)^{\star *}$ & $(4.73)^{\star \star}$ & $(6.38)^{\star \star}$ \\
\hline \multirow[t]{2}{*}{ Coastal } & -0.177 & -0.184 & -0.155 & -0.192 & -0.216 & -0.126 & - & - & - \\
\hline & $(3.83)^{\star *}$ & $(3.33)^{\star \star}$ & $(3.62)^{\star *}$ & $(3.70)^{\star *}$ & $(3.50)^{\star *}$ & $(2.60)^{\star \star}$ & - & - & - \\
\hline \multirow[t]{2}{*}{ Constant } & -0.346 & -0.743 & -0.011 & -0.608 & -0.997 & -0.312 & -0.926 & -1.392 & -0.319 \\
\hline & $(5.04)$ & $(9.48)$ & $(0.17)$ & $(7.73)$ & $(10.71)$ & $(4.26)$ & $(3.00)$ & $(4.03)$ & $(1.06)$ \\
\hline Observations & 28806 & 28806 & 28806 & 24836 & 24836 & 24836 & 3970 & 3970 & 3970 \\
\hline \multirow[t]{2}{*}{ Joint Significance F Test } & $\begin{array}{l}\text { LR } \\
\text { Chi }^{2}(23)\end{array}$ & $\begin{array}{l}\mathrm{LR} \\
\mathrm{Chi}^{2}(23)\end{array}$ & $\begin{array}{l}\mathrm{LR} \\
\mathrm{Chi}^{2}(23)\end{array}$ & $\begin{array}{l}\text { LR } \\
\text { Chi }^{2}(23)\end{array}$ & $\begin{array}{l}\mathrm{LR} \\
\mathrm{Chi}^{2}(23)\end{array}$ & $\begin{array}{l}\mathrm{LR} \\
\mathrm{Chi}^{2}(23)\end{array}$ & $\begin{array}{l}\mathrm{LR} \\
\mathrm{Chi}^{2}(23)\end{array}$ & $\begin{array}{l}\mathrm{LR} \\
\mathrm{Chi}^{2}(23)\end{array}$ & $\begin{array}{l}\text { LR } \\
\text { Chi }^{2}(23)\end{array}$ \\
\hline & $=5742.89^{* *}$ & $=3181.69^{* *}$ & $=964.08^{* *}$ & $=4369.59^{* *}$ & $=1823.48^{\star *}$ & $=883.82^{\star \star}$ & $=6322.34^{\star *}$ & $=4125.35^{\star *}$ & $=907.51^{* *}$ \\
\hline Prob. $>\mathrm{F}$ & 0.0000 & 0.0000 & 0.0000 & 0.0000 & 0.0000 & 0.0000 & 0.0000 & 0.0000 & 0.0000 \\
\hline Pseudo $R^{2}$ & 0.17 & 0.12 & 0.19 & 0.18 & 0.11 & 0.16 & 0.16 & 0.13 & 0.21 \\
\hline
\end{tabular}


Table 12 - Determinants of Poverty in Total Sample, and among Ethnic Majority and Ethnic Minority in 2004

(Conditional fixed-effects logistic regression, with Commune Fixed Effects)

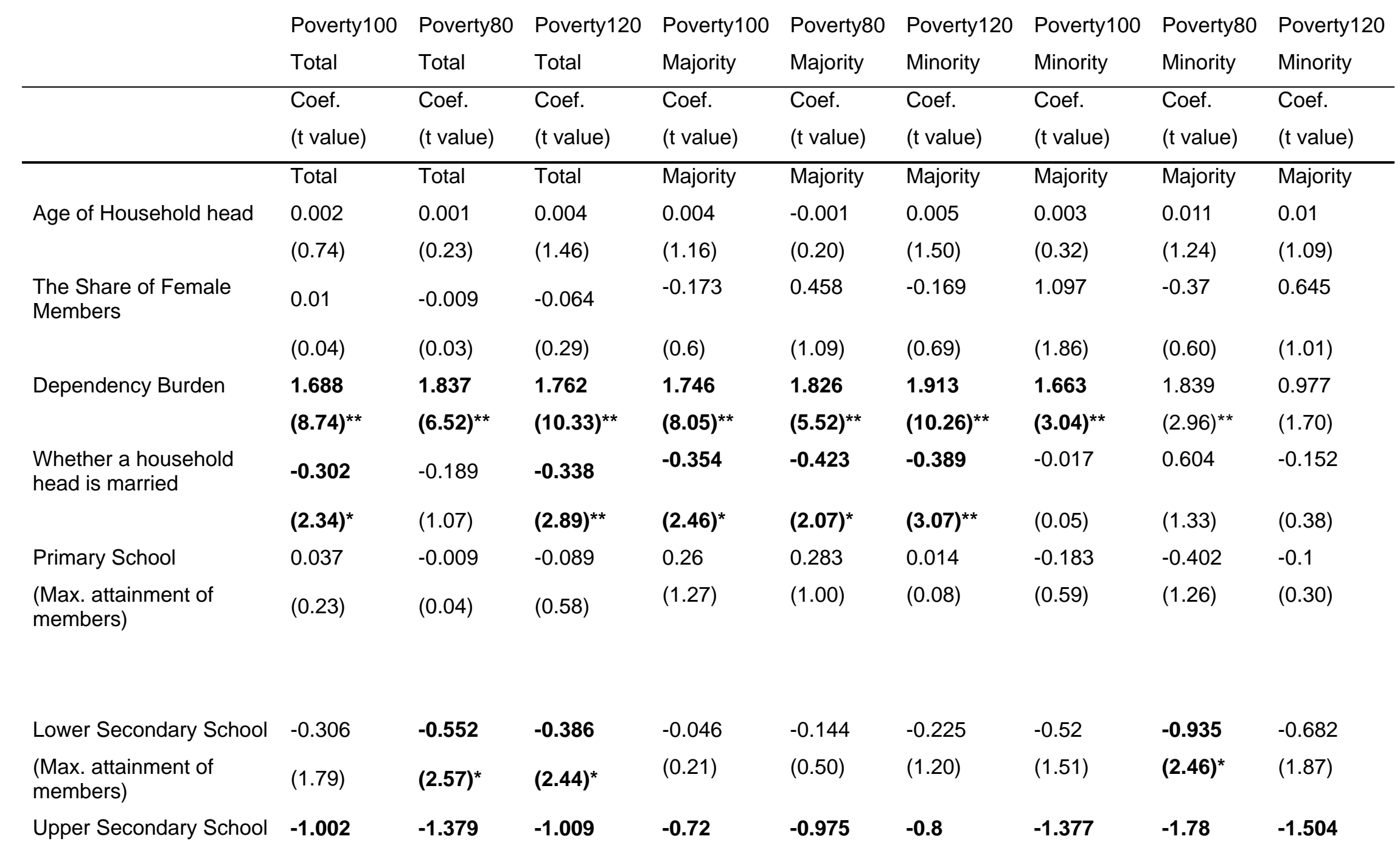




\begin{tabular}{|c|c|c|c|c|c|c|c|c|c|}
\hline $\begin{array}{l}\text { (Max. attainment of } \\
\text { members) }\end{array}$ & $(5.17)^{\star \star}$ & $(5.10)^{\star \star}$ & $(5.87)^{\star \star}$ & $(3.04)^{\star \star}$ & $(2.79)^{\star \star}$ & $(3.98)^{\star \star}$ & $(3.13)^{\star *}$ & $(3.33)^{\star \star}$ & $(3.47)^{\star \star}$ \\
\hline Higher Education & -1.981 & -2.572 & -2.937 & -2.197 & -36.552 & -3.06 & -1.775 & -2.101 & -2.708 \\
\hline $\begin{array}{l}\text { (Max. attainment of } \\
\text { members) }\end{array}$ & $(4.99)^{\star *}$ & $(3.67)^{\star \star}$ & $(7.88)^{\star \star}$ & $(3.78)^{\star \star}$ & $(0.00)$ & $(6.59)^{\star \star}$ & $(2.41)^{\star}$ & $(2.33)^{\star}$ & $(2.97)^{\star \star}$ \\
\hline \multirow[t]{2}{*}{ Land } & -23.197 & -27.46 & -30.524 & 0.004 & -0.001 & 0.005 & 0.003 & 0.011 & 0.01 \\
\hline & $(3.36)^{\star *}$ & $(3.00)^{\star \star}$ & $(4.93)^{\star \star}$ & $(1.16)$ & $(0.20)$ & $(1.50)$ & $(0.32)$ & $(1.24)$ & $(1.09)$ \\
\hline \multirow[t]{2}{*}{ Land2 } & 56.678 & 78.181 & 91.212 & 539.346 & -302.588 & 287.804 & 67.798 & 54.973 & 78.297 \\
\hline & $(2.49)^{\star}$ & $(2.86)^{\star \star}$ & $(3.56)^{\star \star}$ & $(2.87)^{\star \star}$ & $(0.27)$ & $(2.13)^{\star}$ & $(2.12)^{\star}$ & -1.62 & $(2.40)^{\star}$ \\
\hline Observations & 2911 & 1598 & 3853 & 2135 & 985 & 3122 & 588 & 513 & 530 \\
\hline Observations & 6473 & 6473 & 6473 & 5304 & 5304 & 5304 & 1169 & 1169 & 1169 \\
\hline \multirow{2}{*}{ Joint Significance F Test } & $\begin{array}{l}\text { LR } \\
\text { Chi }^{2}(10)\end{array}$ & $\begin{array}{l}\text { LR } \\
\mathrm{Chi}^{2}(10)\end{array}$ & $\begin{array}{l}\text { LR } \\
\mathrm{Chi}^{2}(10)\end{array}$ & $\begin{array}{l}\text { LR } \\
\mathrm{Chi}^{2}(10)\end{array}$ & $\begin{array}{l}\mathrm{LR} \\
\mathrm{Chi}^{2}(10)\end{array}$ & $\begin{array}{l}\text { LR } \\
\mathrm{Chi}^{2}(10)\end{array}$ & $\begin{array}{l}\mathrm{LR} \\
\mathrm{Chi}^{2}(10)\end{array}$ & $\begin{array}{l}\text { LR } \\
\mathrm{Chi}^{2}(10)\end{array}$ & $\begin{array}{l}\text { LR } \\
\text { Chi }^{2}(10)\end{array}$ \\
\hline & $=285.38^{\star *}$ & $=188.86^{\star *}$ & $=444.27^{\star \star}$ & $=230.87^{\star *}$ & $=130.20^{\star \star}$ & $=384.02^{\star *}$ & $=56.10^{\star *}$ & $=51.38^{* *}$ & $=50.06^{* *}$ \\
\hline Prob. >F & 0.0000 & 0.0000 & 0.0000 & 0.0000 & 0.0000 & 0.0000 & 0.0000 & 0.0000 & 0.0000 \\
\hline Number of Communes & 983 & 539 & 1307 & 729 & 337 & 1072 & 204 & 177 & 185 \\
\hline
\end{tabular}

* significant at $5 \%$; ${ }^{* *}$ significant at $1 \%$, Significant coefficients are shown in bold.

Table 13 - Determinants of Poverty in Total Sample, and among Ethnic Majority and Ethnic Minority in 2004

\begin{tabular}{|c|c|c|c|c|c|c|c|c|c|}
\hline & \multicolumn{8}{|c|}{ (Probit Model, with Regional Dummies) } & \multirow[b]{2}{*}{ Poverty 120} \\
\hline & Poverty 100 & Poverty 80 & Poverty 120 & Poverty 100 & Poverty80 & Poverty 120 & Poverty 100 & Poverty 80 & \\
\hline & Total & Total & Total & Majority & Majority & Minority & Minority & Minority & Minority \\
\hline & $\begin{array}{l}\text { Coef. } \\
\text { (t value) }\end{array}$ & $\begin{array}{l}\text { Coef. } \\
\text { (t value) }\end{array}$ & $\begin{array}{l}\text { Coef. } \\
\text { (t value) }\end{array}$ & $\begin{array}{l}\text { Coef. } \\
\text { (t value) }\end{array}$ & $\begin{array}{l}\text { Coef. } \\
\text { (t value) }\end{array}$ & $\begin{array}{l}\text { Coef. } \\
\text { (t value) }\end{array}$ & $\begin{array}{l}\text { Coef. } \\
\text { (t value) }\end{array}$ & $\begin{array}{l}\text { Coef. } \\
\text { (t value) }\end{array}$ & $\begin{array}{l}\text { Coef. } \\
\text { (t value) }\end{array}$ \\
\hline Age of Household head & $\begin{array}{l}-0.002 \\
(1.34)\end{array}$ & $\begin{array}{l}-0.003 \\
(1.91)\end{array}$ & $\begin{array}{l}-0.002 \\
(1.38)\end{array}$ & $\begin{array}{l}-0.001 \\
(0.39)\end{array}$ & $\begin{array}{l}-0.003 \\
(1.44)\end{array}$ & $\begin{array}{l}-0.001 \\
(0.89)\end{array}$ & $\begin{array}{l}0 \\
(0.10)\end{array}$ & $\begin{array}{l}0.002 \\
(0.60)\end{array}$ & $\begin{array}{l}0 \\
(0.10)\end{array}$ \\
\hline
\end{tabular}




\begin{tabular}{|c|c|c|c|c|c|c|c|c|c|}
\hline $\begin{array}{l}\text { The Share of Female } \\
\text { Members }\end{array}$ & $\begin{array}{l}-0.135 \\
(1.29)\end{array}$ & $\begin{array}{l}-0.261 \\
(2.04)^{\star}\end{array}$ & $\begin{array}{l}-0.137 \\
(1.42)\end{array}$ & $\begin{array}{l}-0.118 \\
(0.99)\end{array}$ & $\begin{array}{l}-0.097 \\
(0.63)\end{array}$ & $\begin{array}{l}-0.145 \\
(1.35)\end{array}$ & $\begin{array}{l}0.046 \\
(0.19)\end{array}$ & $\begin{array}{l}-0.477 \\
(1.92)\end{array}$ & $\begin{array}{l}0.063 \\
(0.26)\end{array}$ \\
\hline Dependency Burden & $\begin{array}{l}0.949 \\
(12.28)^{\star \star}\end{array}$ & $\begin{array}{l}0.958 \\
(9.95)^{\star \star}\end{array}$ & $\begin{array}{l}0.862 \\
(12.28)^{\star \star}\end{array}$ & $\begin{array}{l}1.058 \\
(12.24)^{\star \star}\end{array}$ & $\begin{array}{l}1.081 \\
(9.46)^{\star \star}\end{array}$ & $\begin{array}{l}0.981 \\
(12.82)^{\star \star}\end{array}$ & $\begin{array}{l}0.752 \\
(3.78)^{\star \star}\end{array}$ & $\begin{array}{l}0.88 \\
(4.15)^{\star \star}\end{array}$ & $\begin{array}{l}0.381 \\
(1.86)\end{array}$ \\
\hline $\begin{array}{l}\text { Whether a household head } \\
\text { is married }\end{array}$ & $\begin{array}{l}-0.124 \\
(2.23)^{\star}\end{array}$ & $\begin{array}{l}-0.131 \\
(1.93)\end{array}$ & $\begin{array}{l}-0.091 \\
(1.77)\end{array}$ & $\begin{array}{l}-0.191 \\
(3.12)^{\star *}\end{array}$ & $\begin{array}{l}-0.273 \\
(3.53)^{\star \star}\end{array}$ & $\begin{array}{l}-0.13 \\
(2.32)^{\star}\end{array}$ & $\begin{array}{l}-0.078 \\
(0.54)\end{array}$ & $\begin{array}{l}0.17 \\
(1.09)\end{array}$ & $\begin{array}{l}-0.202 \\
(1.32)\end{array}$ \\
\hline $\begin{array}{l}\text { Primary School } \\
\text { (Max. attainment of } \\
\text { members) }\end{array}$ & $\begin{array}{l}-0.142 \\
(2.22)^{\star}\end{array}$ & $\begin{array}{l}-0.216 \\
(3.08)^{\star \star}\end{array}$ & $\begin{array}{l}-0.099 \\
(1.58)\end{array}$ & $\begin{array}{l}0.093 \\
(1.12)\end{array}$ & $\begin{array}{l}0.083 \\
(0.80)\end{array}$ & $\begin{array}{l}0.029 \\
(0.38)\end{array}$ & $\begin{array}{l}-0.272 \\
(2.41)^{\star}\end{array}$ & $\begin{array}{l}-0.353 \\
(3.25)^{\star *}\end{array}$ & $\begin{array}{l}-0.058 \\
(0.47)\end{array}$ \\
\hline $\begin{array}{l}\text { Lower Secondary School } \\
\text { (Max. attainment of } \\
\text { members) }\end{array}$ & $\begin{array}{l}-0.308 \\
(4.88)^{\star \star}\end{array}$ & $\begin{array}{l}-0.46 \\
(6.48)^{\star \star}\end{array}$ & $\begin{array}{l}-0.241 \\
(3.92)^{\star \star}\end{array}$ & $\begin{array}{l}0.039 \\
(0.47)\end{array}$ & $\begin{array}{l}-0.009 \\
(0.09)\end{array}$ & $\begin{array}{l}-0.014 \\
(0.19)\end{array}$ & $\begin{array}{l}-0.602 \\
(5.12)^{\star \star}\end{array}$ & $\begin{array}{l}-0.753 \\
(6.38)^{\star \star}\end{array}$ & $\begin{array}{l}-0.42 \\
(3.39)^{\star \star}\end{array}$ \\
\hline $\begin{array}{l}\text { Upper Secondary School } \\
\text { (Max. attainment of } \\
\text { members) }\end{array}$ & $\begin{array}{l}-0.735 \\
(10.28)^{\star \star}\end{array}$ & $\begin{array}{l}-0.883 \\
(10.08)^{\star \star}\end{array}$ & $\begin{array}{l}-0.672 \\
(10.03)^{\star \star}\end{array}$ & $\begin{array}{l}-0.353 \\
(3.96)^{\star \star}\end{array}$ & $\begin{array}{l}-0.398 \\
(3.41)^{\star \star}\end{array}$ & $\begin{array}{l}-0.403 \\
(5.01)^{\star \star}\end{array}$ & $\begin{array}{l}-1.152 \\
(7.58)^{\star \star}\end{array}$ & $\begin{array}{l}-1.241 \\
(7.28)^{\star \star}\end{array}$ & $\begin{array}{l}-1.075 \\
(7.11)^{\star \star}\end{array}$ \\
\hline $\begin{array}{l}\text { Higher Education } \\
\text { (Max. attainment of } \\
\text { members) }\end{array}$ & $\begin{array}{l}-1.48 \\
(8.35)^{\star \star}\end{array}$ & $\begin{array}{l}-1.537 \\
(5.53)^{\star \star}\end{array}$ & $\begin{array}{l}-1.55 \\
(10.92)^{\star \star}\end{array}$ & $\begin{array}{l}-1.374 \\
(5.77)^{\star \star}\end{array}$ & - & $\begin{array}{l}-1.612 \\
(8.63)^{\star \star}\end{array}$ & $\begin{array}{l}-1.265 \\
(3.70)^{\star \star}\end{array}$ & $\begin{array}{l}-1.236 \\
(3.08)^{\star \star}\end{array}$ & $\begin{array}{l}-0.96 \\
(3.11)^{\star \star}\end{array}$ \\
\hline Land & $\begin{array}{l}-9.986 \\
(4.81)^{\star \star}\end{array}$ & $\begin{array}{l}-7.353 \\
(2.95)^{\star \star}\end{array}$ & $\begin{array}{l}-12.792 \\
(6.43)^{\star \star}\end{array}$ & $\begin{array}{l}-17.248 \\
(5.44)^{\star \star}\end{array}$ & $\begin{array}{l}-10.439 \\
(0.90)\end{array}$ & $\begin{array}{l}-23.39 \\
(6.89)^{\star \star}\end{array}$ & $\begin{array}{l}-10.053 \\
(3.33)^{\star \star}\end{array}$ & $\begin{array}{l}-6.576 \\
(2.03)^{\star}\end{array}$ & $\begin{array}{l}-12.136 \\
(3.94)^{\star \star}\end{array}$ \\
\hline Land2 & $\begin{array}{l}27.061 \\
(3.34)^{\star \star}\end{array}$ & $\begin{array}{l}21.708 \\
(2.40)^{\star}\end{array}$ & $\begin{array}{l}48.592 \\
(4.66)^{\star \star}\end{array}$ & $\begin{array}{l}53.509 \\
(3.76)^{\star \star}\end{array}$ & $\begin{array}{l}-302.797 \\
(0.78)\end{array}$ & $\begin{array}{l}137.001 \\
(4.18)^{\star \star}\end{array}$ & $\begin{array}{l}24.883 \\
(2.36)^{\star}\end{array}$ & $\begin{array}{l}19.385 \\
(1.76)\end{array}$ & $\begin{array}{l}35.85 \\
(2.88)^{\star \star}\end{array}$ \\
\hline Buddhist & $\begin{array}{l}-0.27 \\
(6.55)^{\star \star}\end{array}$ & $\begin{array}{l}-0.341 \\
(6.59)^{\star \star}\end{array}$ & $\begin{array}{l}-0.172 \\
(4.58)^{\star \star}\end{array}$ & $\begin{array}{l}-0.172 \\
(3.77)^{\star \star}\end{array}$ & $\begin{array}{l}-0.268 \\
(4.53)^{\star \star}\end{array}$ & $\begin{array}{l}-0.066 \\
(1.61)\end{array}$ & $\begin{array}{l}-0.223 \\
(1.60)\end{array}$ & $\begin{array}{l}-0.127 \\
(0.86)\end{array}$ & $\begin{array}{l}-0.196 \\
(1.37)\end{array}$ \\
\hline Catholic & -0.279 & -0.337 & -0.234 & -0.141 & -0.196 & -0.088 & -0.197 & -0.264 & -0.227 \\
\hline
\end{tabular}




\begin{tabular}{|c|c|c|c|c|c|c|c|c|c|}
\hline & $(4.60)^{\star \star}$ & $(4.53)^{\star *}$ & $(4.18)^{\star *}$ & $(1.97)^{\star}$ & $(2.10)^{\star}$ & $(1.37)$ & $(1.54)$ & $(1.94)$ & $(1.73)$ \\
\hline \multirow[t]{2}{*}{ InlandDelta } & 0.007 & -0.023 & 0.01 & 0.019 & -0.023 & 0.022 & -0.19 & 0.377 & -0.175 \\
\hline & $(0.09)$ & $(0.24)$ & $(0.15)$ & $(0.25)$ & $(0.22)$ & $(0.31)$ & $(0.53)$ & $(0.78)$ & $(0.52)$ \\
\hline \multirow[t]{2}{*}{ LowMountains } & 0.348 & 0.367 & 0.298 & 0.192 & 0.173 & 0.143 & 0.226 & 0.69 & 0.25 \\
\hline & $(4.18)^{\star \star}$ & $(3.50)^{\star \star}$ & $(3.95)^{\star \star}$ & $(2.11)^{\star}$ & $(1.49)$ & $(1.75)$ & $(0.68)$ & $(1.49)$ & $(0.80)$ \\
\hline \multirow[t]{2}{*}{ HighMountains } & 0.704 & 0.712 & 0.659 & 0.118 & 0.126 & 0.122 & 0.404 & 0.818 & 0.424 \\
\hline & $(8.38)^{\star \star}$ & $(6.87)^{\star \star}$ & $(8.54)^{\star *}$ & $(1.08)$ & $(0.90)$ & $(1.25)$ & $(1.22)$ & $(1.78)$ & $(1.36)$ \\
\hline \multirow[t]{2}{*}{ Coastal } & 0.132 & 0.027 & 0.094 & 0.136 & 0.07 & 0.096 & 0.279 & -0.277 & 0.204 \\
\hline & $(1.32)$ & $(0.21)$ & $(1.04)$ & $(1.32)$ & $(0.52)$ & $(1.04)$ & $(0.57)$ & $(0.38)$ & $(0.43)$ \\
\hline \multirow[t]{2}{*}{ Constant } & -0.444 & -0.76 & -0.042 & -0.846 & -1.195 & -0.311 & 0.163 & -0.909 & 0.676 \\
\hline & $(2.94)$ & $(4.21)$ & $(0.30)$ & $(4.80)$ & $(5.34)$ & $(1.95)$ & $(0.38)$ & $(1.67)$ & $(1.58)$ \\
\hline Observations & 6473 & 6473 & 6473 & 5304 & 5304 & 5304 & 1169 & 1169 & 1169 \\
\hline \multirow{2}{*}{ Joint Significance F Test } & $\begin{array}{l}\text { LR } \\
\text { Chi }^{2}(16)\end{array}$ & $\begin{array}{l}\text { LR } \\
\text { Chi }^{2}(16)\end{array}$ & $\begin{array}{l}\text { LR } \\
\operatorname{Chi}^{2}(16)\end{array}$ & $\begin{array}{l}\text { LR } \\
\mathrm{Chi}^{2}(16)\end{array}$ & $\begin{array}{l}\text { LR } \\
\text { Chi }^{2}(16)\end{array}$ & $\begin{array}{l}\text { LR } \\
\mathrm{Chi}^{2}(16)\end{array}$ & $\begin{array}{l}\text { LR } \\
\text { Chi }^{2}(16)\end{array}$ & $\begin{array}{l}\text { LR } \\
\mathrm{Chi}^{2}(16)\end{array}$ & $\begin{array}{l}\mathrm{LR} \\
\mathrm{Chi}^{2}(16)\end{array}$ \\
\hline & $=948.88^{\star *}$ & $=776.67^{* *}$ & $=968.83^{* *}$ & $=452.59^{* *}$ & $=250.98^{\star *}$ & $=576.47^{\star *}$ & $=175.40^{* *}$ & $=173.76^{\star *}$ & $=147.80^{* *}$ \\
\hline Prob. $>\mathrm{F}$ & 0.0000 & 0.0000 & 0.0000 & 0.0000 & 0.0000 & 0.0000 & 0.0000 & 0.0000 & 0.0000 \\
\hline Pseudo $\mathrm{R}^{2}$ & 0.1311 & 0.1633 & 0.1120 & 0.0889 & 0.0912 & 0.0862 & 0.1084 & 0.1171 & 0.1003 \\
\hline
\end{tabular}




\subsection{Decomposition Analysis}

\section{Poverty Decomposition}

Since the predictions of conditional fixed-effects logistic regression are much lower than the actual poverty, which would make the decomposition analysis difficult, we use the probit model with religion and regional dummies as the base regression. In 2002, the share of the structural component is much larger than the characteristic component, ranging from $72 \%$ to $82 \%$. While the structural component includes not only the returns to household characteristics but also the returns to (or the effects of) being located in a particular region, our analysis suggests that the difference in poverty between the ethnic majority and ethnic minority groups is largely structural. That does not necessarily rule out targeted interventions (e.g., to concentrate resources for education on particular ethnic minorities). Rather, our results suggest that, for example, efforts to increase returns to education by improving its quality would be potentially more important.

The second panel of Table 14 for 2004 reinforces this view. The results suggest that more than $90 \%$ of the poverty difference is structural.

Appendices 2 and 3 show the decomposition of the above results by each explanatory variable. The results vary according to the poverty line chosen. If, for example, we choose the national poverty line, the structural factors are mainly associated with location, religion, other household characteristics and education (only in 2002).

\section{Expenditure Decomposition}

Generally consistent with van de Walle and Gunewardena (2001), structural factors are dominant when commune fixed effects are taken into account. The first and the last panels in Table 15 show that $95 \%-97 \%$ of the difference of log per capita expenditure is associated with the structural component.

The case without commune fixed effects, based on the data for 2002, shows that the characteristic component increases to $33 \%$, while the structural component reduces to $67 \%$, consistent with van de Walle and Gunewardena (2001) ${ }^{12}$. However, the structural component is considerably more dominant $(96 \%)$ in 2004 , without commune effects.

It is shown in Appendices 4 and 5 that the decomposition by each explanatory variable varies considerably depending on the year or the specification used. However, if we focus only on the decomposition of the structural factors -dominant in all cases- with commune fixed effects, household characteristics are the most important, followed by land, in both 2002 and 2004. Without commune fixed effects, however, education is the most important in the structural component, in both 2002 and 2004.

\section{Conclusion}

The present study examined why ethnic minorities are poorer than ethnic majorities in Vietnam, using the VHLSS data for 2002 and 2004. Some important findings are summarised below from a broad policy perspective.

First, our analysis confirms that households belonging to ethnic minority groups are not only poorer but also more vulnerable to various shocks than those in the majority groups, namely the Kinh and the Chinese. Second, household composition (e.g. dependency burden), education, land holdings, and location are important determinants of expenditure and poverty, whilst there is some diversity among different ethnic groups. Finally, the decompositions reveal that ethnic minorities are poorer not necessarily because they are more disadvantaged in terms of household characteristics (e.g. educational attainment or location), but, more importantly, because the returns are much lower for them than for majority groups. So it is

\footnotetext{
${ }^{12}$ They report that, using the data for $1992 / 3$, about one- half is explained by the characteristic component and another half by the structural component, if commune fixed effects are ignored.
} 
imperative that government policies concentrate on not just enhancing the endowments of the minorities but also seek to reduce the disparities in the returns to such endowments between them and the majority. Policy priorites from this perspective are to improve the quality of education that minorities receive, and build better infrastructure in remote areas to promote easier market access and better livelihood prospects for them.

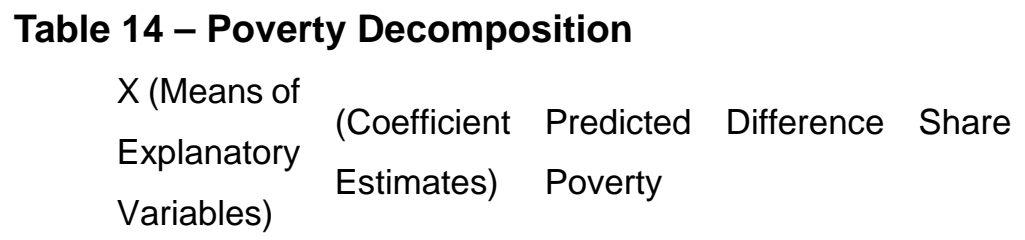

2002

Based on Probit Model (with Regional Dummies)

Predicted Poverty (100\%) for Majority

Majority Majority $\quad 0.22$

(based on coefficient estimates for Majority)

0.10

$23.5 \%$

Characteristic

Predicted Poverty (100\%) for Minority

Minority Majority $\quad 0.32$

(based on coefficient estimates for Majority)

$76.5 \%$ Structural

Predicted Poverty (100\%) for Minority

Minority Minority $\quad 0.64$

(based on coefficient estimates for Minority)

Predicted Poverty (80\%) for

Majority

Majority $\quad$ Majority $\quad 0.11$

(based on coefficient estimates for Majority)

0.06

$17.8 \%$

Characteristic

Predicted Poverty (80\%) for

Minority

Minority Majority $\quad 0.17$

(based on coefficient estimates for Majority)

82.2\% Structural

Predicted Poverty (80\%) for

Minority

Minority Minority $\quad 0.46$

(based on coefficient estimates for Minority)

Predicted Poverty (120\%) for Majority

Majority Majority $\quad 0.35$

(based on coefficient estimates for Majority)

0.12

28.1\% Characteristic

Predicted Poverty (120\%) for

Minority

Minority Majority $\quad 0.47$

(based on coefficient estimates for

$71.9 \%$ Structural 
Predicted Poverty (120\%) for Minority

Minority Minority $\quad 0.76$

(based on coefficient estimates for

Minority)

\section{4}

Based on Probit Model (with Regional

Dummies)

Predicted Poverty (100\%) for

Majority

Majority $\quad$ Majority $\quad 0.19$

(based on coefficient estimates for

Majority)

0.03

Predicted Poverty (100\%) for

Minority

Minority $\quad$ Majority $\quad 0.21$

(based on coefficient estimates for Majority)

91.8\% Structural

Predicted Poverty (100\%) for

Minority

Minority Minority $\quad 0.53$

(based on coefficient estimates for

Minority)

Predicted Poverty (80\%) for

Majority

Majority $\quad$ Majority $\quad 0.08$

(based on coefficient estimates for Majority)

0.02

$7.8 \%$

Characteristic

Predicted Poverty (80\%) for

Minority

Minority Majority $\quad 0.10$

(based on coefficient estimates for Majority)

0.23

92.2\% Structural

Predicted Poverty (80\%) for

Minority

Minority Minority $\quad 0.33$

(based on coefficient estimates for Minority)

Predicted Poverty (120\%) for Majority

Majority $\quad$ Majority $\quad 0.32$

(based on coefficient estimates for Majority)

0.02

$6.8 \%$

Characteristic

Predicted Poverty (120\%) for

Minority

Minority Majority $\quad 0.35$

(based on coefficient estimates for Majority)

0.33

$93.2 \%$

Structural

Predicted Poverty (120\%) for Minority

Minority $\quad$ Minority $\quad 0.68$

(based on coefficient estimates for Minority) 
Table 15 - Expenditure Inequality Decomposition

$\begin{array}{llll}X \text { (Means of } & \text { (Coefficient } & \text { Predicted Difference Share } \\ \text { Explanatory } & \text { Estimates) } & \text { Poverty } & \\ \text { Variables) } & & \end{array}$

2002

Based on OLS with Commune Fixed Effects

Predicted log per capita consumption for Majority

Majority Majority $\quad \mathbf{8 . 0 3}$

(based on coefficient estimates for

Majority)

$-0.03$

$4.6 \%$

Characteristic

Component

Predicted log per capita consumption

for Minority

Minority Majority $\quad \mathbf{8 . 0 0}$

(based on coefficient estimates for

Majority)

$-0.57$

$95.4 \%$

Structural

Predicted log per capita consumption

for Minority

Minority Minority $\quad \mathbf{7 . 4 3}$

(based on coefficient estimates for

Minority)

Based on OLS without Commune Fixed Effects, with Regional Dummies

Predicted log per capita consumption

for Majority

Majority Majority $\quad \mathbf{8 . 0 3}$

(based on coefficient estimates for

Majority)

$-0.19$

$32.6 \%$

Characteristic

Predicted log per capita consumption for Minority

Minority Majority $\quad \mathbf{7 . 8 3}$

(based on coefficient estimates for

Majority)

$-0.40$

$67.4 \%$

Structural

Component

Predicted log per capita consumption for Minority

Minority Minority $\quad \mathbf{7 . 4 3}$

(based on coefficient estimates for Minority)

2004

Based on OLS with Commune Fixed Effects

Predicted log per capita consumption for Majority

Majority Majority $\quad \mathbf{8 . 2 4}$

(based on coefficient estimates for

Majority)

Predicted log per capita consumption

for Minority

Minority Majority $\mathbf{8 . 2 2}$

(based on coefficient estimates for

Majority)

Predicted log per capita consumption

for Minority

Minority Minority $\quad \mathbf{7 . 7 0}$

(based on coefficient estimates for

Minority)

$-0.02$

$2.8 \%$

Characteristic

Component 
Based on OLS without Commune Fixed Effects, with Regional Dummies

Predicted log per capita consumption for Majority

Majority

Majority

8.10

(based on coefficient estimates for Majority)

Predicted log per capita consumption for Minority

(based on coefficient estimates for Majority)

Predicted log per capita consumption for Minority

Minority

Minority

Majority

$3.7 \%$

Characteristic

Component

(based on coefficient estimates for Minority) 


\section{References}

ADB (Asian Development Bank) (2002) Indigenous Peoples / Ethnic Minorities and Poverty Reduction - Viet Nam. Manila, Philippines: ADB.

Blinder, A.S. (1973) Wage discrimination: reduced form and structural estimates, Journal of Human Resources, 8, 436-455.

Borooah, V.K. (2005) Caste, Inequality and Poverty in India, Review of Development Economics, 9, 399-414.

Chaudhuri, S., Jalan, J. and Suryahadi, A. (2002) Assessing Household Vulnerability to Poverty from Cross-Sectional Data: A Methodology and Estimates from Indonesia, Discussion Paper. New York, NY: Columbia University.

Imai, K., Gaiha, R., and Kang, W. (2007) Poverty Dynamics and Vulnerability in Vietnam, Economics Discussion Paper, 0708-2007. Manchester, UK: University of Manchester.

Kijima, Y. (2006) Caste and Tribe Inequality: Evidence from India, 1983-1999, Economic Development and Cultural Change, 54, 369-404.

Fforde, A. (1998) Vulnerable Groups in Rural Vietnam: Situation and Policy Response. A Report based upon the Sample survey. Available on-line at http://www.aduki.com.au/Vulnerable\%20Groups.pdf. Accessed May 22, 2007.

Fforde, A. (2005) Persuasion: Reflections on economics, data, and the 'homogeneity assumption', Journal of Economic Methodology, 12 (1), 63-91.

Gaiha, R. and Thapa, G. (2006) Growth, Equity and Poverty Reduction in Vietnam-Prospects and Challenges. Rome, Italy: Asia and Pacific Division, the IFAD, December 2006.

Gaiha, R., G. Thapa, K. Imai and Vani S. Kulkarni. (2007) Endowments, Discrimination and Poverty in Rural India. Rome, Italy: IFAD.

Gang, I.N., Sen, K., and Yun, M. (2006) 'Poverty in Rural India: Ethnicity and Caste', Draft.

McElwee, P. (2006) Blood Relatives or Uneasy Neighbors?: Kinh - Ethnic Minority Interactions in the Annamite Mountains. A Draft Presented at the Conference 'Vietnam Update 2006' at Research School of Pacific and Asian Studies, the Australian National University.

Oaxaca, R.L. (1973) Male-female wage differentials in urban labor markets, International Economic Review, 9, 693-709.

Scott, S. and Chuyen, T.T.K. (2004) Behind the numbers: Social mobility, regional disparities and new trajectories of development in rural Vietnam IN Taylor, P. (Ed.), Social Inequality in Vietnam: Challenges to Reform. Singapore: Institute of Southeast Asian Studies (ISEAS), 90-122.

van de Walle, D. and Gunewardena, D. (2001) Sources of ethnic inequality in Viet Nam, Journal of Development Economics, 65, 177-207.

World Bank (2004) Vietnam Development Report 2004: Poverty. Hanoi, Vietnam: World Bank.

Yun, M. (2004) Decomposing differences in the first moment, Economics Letters, 82 (2), 275-280. 


\section{Appendix $1^{13}$}

Vulnerability is simply defined as the probability that a household will fall into poverty in the future.

$$
\mathrm{VEP}_{\mathrm{it}} \equiv \mathrm{V}_{\mathrm{it}}=\operatorname{Pr}\left(\mathrm{c}_{\mathrm{i}, \mathrm{t}+1} \leq \mathrm{z}\right)
$$

where vulnerability of household $i$ at time $t, V_{i t}$, is the probability that the $i$-th household's level of consumption at time $t+1, c_{i, t+1}$, will be below the poverty line, $z$. One of the limitations of this definition of vulnerability is that it is sensitive to the choice of $z$.

This can be derived by estimating the consumption function:

$$
\ln \mathrm{c}_{\mathrm{i}}=\mathrm{X}_{\mathrm{i}} \beta+\mathrm{e}_{\mathrm{i}}
$$

where $c_{i}$ is per capita expenditure (i.e. food and non-food consumption expenditure) for the $i$-th household, $\mathrm{X}_{\mathrm{i}}$ represents a bundle of observable household characteristics and other determinants of consumption (e.g. age of household head, dependency burden, educational attainments of household members, ethnic group, regional dummies, access to market, infrastructure), $\beta$ is a vector of coefficients of household characteristics, and $e_{i}$ is a mean-zero disturbance term that captures idiosyncratic shocks to per capita consumption. It is assumed that the structure of the economy is relatively stable over time and, hence, future consumption stems solely from the uncertainty about the idiosyncratic shocks, $e_{i}$. It is also assumed that the variance of the disturbance term depends on:

$$
\sigma_{\mathrm{e}, \mathrm{i}}^{2}=\mathrm{X}_{\mathrm{i}} \theta
$$

The estimates of $\beta$ and $\theta$ are obtained using a three-step feasible generalized least squares (FGLS). Using the estimates $\hat{\beta}$ and $\hat{\theta}$, we can compute the expected log consumption and the variance of log consumption for each household as follows.

$$
\mathrm{E}\left[\ln \mathrm{C}_{\mathrm{i}} \mid \mathrm{X}_{\mathrm{i}}\right]=\mathrm{X}_{\mathrm{i}} \hat{\beta}(\mathrm{A} 4) \quad \mathrm{V}\left[\ln \mathrm{C}_{\mathrm{i}} \mid \mathrm{X}_{\mathrm{i}}\right]=\mathrm{X}_{\mathrm{i}} \hat{\boldsymbol{\theta}}
$$

By assuming $\ln c_{h}$ as normally distributed, the estimated probability that a household will be poor in the future (say, at time $t+1$ ) is given by:

$$
\mathrm{VE \hat {E }}{ }_{\mathrm{i}} \equiv \hat{\mathrm{V}}_{\mathrm{i}}=\hat{\operatorname{Pr}}\left(\ln \mathrm{c}_{\mathrm{i}}<\ln \mathrm{z} \mid \mathrm{X}_{\mathrm{i}}\right)=\Phi\left(\frac{\ln \mathrm{z}-\mathrm{X}_{\mathrm{i}} \hat{\beta}}{\sqrt{\mathrm{X}_{\mathrm{i}} \hat{\theta}}}\right)
$$

\footnotetext{
${ }^{13}$ See Imai, Gaiha and Kang (2007) for more details.
} 


\section{Appendix 2}

Decomposition of Poverty by Explanatory Variable 2002 (\%)

\begin{tabular}{|c|c|c|c|c|c|c|c|c|c|c|c|c|c|}
\hline & & $\begin{array}{l}\text { Poverty } \\
100 \%\end{array}$ & & & & Poverty $80 \%$ & & & & Poverty $120 \%$ & & & \\
\hline & & Characteristic & & Structural & & Characteristic & & Structural & & Characteristic & & Structural & \\
\hline & & Component & & Component & & Component & & Component & & Component & & Component & \\
\hline Headage & & 7.0 & & 34.4 & & 7.7 & & 90.8 & & 6.5 & & 12.4 & \\
\hline Femaleshare & & -0.5 & & -6.3 & & -0.6 & & -0.3 & & -0.5 & & 46.4 & \\
\hline Depburden & & 13.3 & & -15.0 & & 12.7 & & -7.8 & & 12.7 & & 6.8 & \\
\hline Married & Household & 0.2 & & 131.9 & & -1.0 & & 141.5 & & 1.1 & & -141.2 & \\
\hline Primary & Characteristics & -0.6 & 19.4 & -58.2 & 86.8 & -0.3 & 18.6 & -67.1 & 157.3 & -0.5 & 19.3 & 82.7 & 7.1 \\
\hline Lower_Secondary & & 2.2 & & -78.6 & & 3.3 & & -95.5 & & 1.8 & & 115.9 & \\
\hline Upper_Secondary & & 13.5 & & -25.6 & & 13.9 & & -30.5 & & 14.3 & & 34.3 & \\
\hline TechnicalS I & & 8.7 & & -14.4 & & 8.6 & & -18.5 & & 8.6 & & 27.1 & \\
\hline HigherEduc n & Education & 23.9 & 48.3 & -6.3 & -124.9 & 21.9 & 47.7 & -7.6 & -152.1 & 24.7 & 49.4 & 9.8 & 187.1 \\
\hline Agriland & & 31.8 & & -145.2 & & 11.8 & & -140.0 & & 45.4 & & 232.0 & \\
\hline Agriland2 & & -37.9 & & 136.8 & & -30.2 & & 154.0 & & -39.1 & & -185.6 & \\
\hline Sylvicultural Land & & 6.5 & & -20.1 & & 13.5 & & -56.4 & & 3.7 & & 17.2 & \\
\hline Sylvicultural Land2 & & -3.0 & & 8.7 & & -3.9 & & 18.4 & & -0.2 & & -3.4 & \\
\hline Waterland & & 0.5 & & -3.0 & & -0.3 & & -3.9 & & 0.7 & & -3.5 & \\
\hline Waterland2 & & 0.2 & & 0.9 & & 2.9 & & 3.3 & & -0.2 & & 6.6 & \\
\hline Unusedland & & -1.1 & & 11.5 & & -2.0 & & 14.8 & & -0.9 & & -14.9 & \\
\hline Unusedland2 & Land & 0.1 & -2.9 & -7.1 & -17.7 & 0.1 & -8.1 & -7.4 & -17.1 & 0.0 & 9.5 & 8.7 & 57.0 \\
\hline Coastal & & 2.2 & & -3.6 & & 2.3 & & -5.3 & & 1.7 & & 5.5 & \\
\hline
\end{tabular}

Table cont. 


\begin{tabular}{|c|c|c|c|c|c|c|c|c|c|c|c|c|c|}
\hline Inland Delta & & 7.1 & & -22.4 & & 10.2 & & -49.4 & & -1.0 & & 26.7 & \\
\hline Low Mountains & & 4.8 & & 19.4 & & 4.9 & & 7.7 & & 6.1 & & -7.7 & \\
\hline High Mountains & Location & 13.3 & 27.4 & 122.7 & 116.1 & 16.8 & 34.1 & 92.5 & 45.5 & 7.2 & 14.0 & -148.0 & -123.5 \\
\hline \multirow[t]{2}{*}{ Catholic } & Religion & 0.0 & 7.8 & 0.5 & 39.7 & 0.0 & 7.7 & 3.8 & 66.4 & 0.0 & 7.9 & 5.4 & -27.7 \\
\hline & & & 100 & & 100 & & 100 & & 100 & & 100 & & 100 \\
\hline
\end{tabular}

\section{Appendix 3}

\section{Decomposition of Poverty by Explanatory Variable 2004 (\%)}

\begin{tabular}{|c|c|c|c|c|c|c|c|c|c|c|c|c|c|}
\hline & & Poverty $100 \%$ & & & & Poverty $80 \%$ & & & & $\begin{array}{l}\text { Poverty } \\
120 \%\end{array}$ & & & \\
\hline & & Characteristic & & Structural & & Characteristic & & Structural & & Characteristic & & Structural & \\
\hline & & Component & & Component & & Component & & Component & & Component & & Component & \\
\hline Headage & & 1.6 & & -14.5 & & 243.5 & & 21.2 & & -12.4 & & -133.1 & \\
\hline Femaleshare & & 1.3 & & -90.6 & & 33.9 & & -23.2 & & -5.0 & & -184.8 & \\
\hline Depburden & Household & 23.7 & & 126.7 & & 787.9 & & -4.8 & & 72.4 & & 329.2 & \\
\hline Married & Characteristics & -9.0 & 17.6 & -111.0 & -89.4 & -417.2 & 648.2 & 41.7 & 34.9 & 19.5 & 74.5 & 103.1 & 114.5 \\
\hline Primary & & 5.8 & & 133.4 & & 166.9 & & -13.8 & & 1.1 & & 30.3 & \\
\hline Lower_Seco y & & -0.7 & & 205.7 & & 5.0 & & -22.5 & & -5.6 & & 183.6 & \\
\hline Upper_Seco y & & 25.3 & & 133.5 & & 925.8 & & -13.2 & & -7.1 & & 337.0 & \\
\hline HigherEduc n & Education & 49.2 & 79.6 & -3.2 & 469.4 & . & 1097.7 & . & -49.5 & 529.9 & 518.3 & -168.8 & 382.0 \\
\hline Land & & -85.0 & & -119.6 & & -1672.5 & & 7.9 & & 275.9 & & -139.8 & \\
\hline Land 2 & Land & 18.2 & -66.7 & 26.4 & -93.2 & -3354.8 & -5027.3 & 31.8 & 39.7 & -171.8 & 104.1 & 63.3 & -76.5 \\
\hline
\end{tabular}

Table cont. 


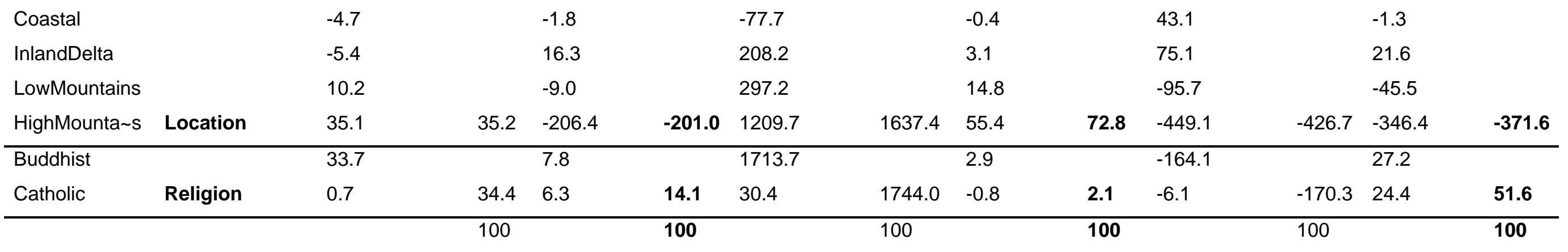

\section{Appendix 4}

Decomposition of Consumption Inequality by Explanatory Variable 2002 (\%)

\begin{tabular}{|c|c|c|c|c|c|c|c|c|c|}
\hline & & With commun & fixed ef & & & With regional & lummies & & \\
\hline & & Characteristic & & Structural & & Characteristic & & Structural & \\
\hline & & Component & & Component & & Component & & Component & \\
\hline Headage & & 13.5 & & 115.9 & & 2.7 & & $\begin{array}{l}-29.6 \\
\end{array}$ & \\
\hline Femaleshare & & -1.3 & & -3.1 & & -0.2 & & -0.1 & \\
\hline Depburden & Household & 55.9 & & 8.3 & & 10.4 & & 31.6 & \\
\hline Married & Characteristics & 5.4 & 73.5 & 153.5 & 274.7 & 3.4 & 16.3 & -15.6 & -13.7 \\
\hline Primary & & 17.9 & & -96.8 & & -0.3 & & 59.2 & \\
\hline Lower_Secondary & & 11.2 & & -84.6 & & 2.4 & & 82.3 & \\
\hline Upper_Secondary & & 59.4 & & -19.7 & & 14.5 & & 17.4 & \\
\hline Technical School & & 32.6 & & -9.0 & & 7.8 & & 16.0 & \\
\hline Higher Education & Education & 91.5 & 212.7 & -9.3 & -219.4 & 24.3 & 48.8 & 7.5 & 182.4 \\
\hline
\end{tabular}

Table cont. 


\begin{tabular}{|c|c|c|c|c|c|c|c|c|c|}
\hline Agriland & & -133.9 & & -41.1 & & -2.6 & & 48.0 & \\
\hline Agriland2 & & 2.8 & & 29.4 & & 0.0 & & -6.6 & \\
\hline Sylvicultural Land & & -142.1 & & 102.2 & & 6.3 & & 22.1 & \\
\hline $\begin{array}{l}\text { Sylvicultural } \\
\text { Land2 }\end{array}$ & & 81.3 & & -74.1 & & -3.3 & & -10.2 & \\
\hline Waterland & & 6.8 & & -36.9 & & 0.6 & & -0.1 & \\
\hline Waterland2 & & -0.8 & & 60.8 & & 0.5 & & -0.5 & \\
\hline Unusedland & & -0.3 & & 13.6 & & -1.0 & & -9.7 & \\
\hline Unusedland2 & Land & 0.0 & -186.2 & -9.1 & 44.7 & 0.1 & 0.6 & 5.0 & 48.0 \\
\hline Coastal & & - & & - & & 3.1 & & 4.1 & \\
\hline InlandDelta & & - & & - & & 5.6 & & 28.6 & \\
\hline Low Mountains & & - & & - & & 7.7 & & 8.1 & \\
\hline High Mountains & Regions & - & - & - & - & 11.0 & 27.4 & -113.1 & -72.3 \\
\hline Buddhist & & - & & - & & 7.0 & & -43.2 & \\
\hline \multirow[t]{2}{*}{ Catholic } & Religion & - & - & - & - & 0.0 & 7.0 & -1.2 & -44.4 \\
\hline & & & 100 & & 100 & & $100]$ & & 100 \\
\hline
\end{tabular}




\section{Appendix 5}

Decomposition of Consumption Inequality by Explanatory Variable 2004 (\%)

\begin{tabular}{|c|c|c|c|c|c|c|c|c|c|}
\hline & & \multicolumn{4}{|c|}{ With commune fixed effects } & \multicolumn{4}{|c|}{ With regional dummies } \\
\hline & & Characteristic & & Structural & & Characteristic & & Structural & \\
\hline & & Component & & Component & & Component & & Component & \\
\hline Headage & & -18.5 & & 470.4 & & 279.9 & & -206.9 & \\
\hline Femaleshare & & -3.6 & & 4.8 & & 57.2 & & 113.5 & \\
\hline Depburden & Household & 98.6 & & -55.5 & & 1133.9 & & 110.4 & \\
\hline Married & Characterestics & -38.0 & 38.6 & 341.3 & 761.0 & -328.1 & 1142.9 & -35.6 & -18.6 \\
\hline Primary & & 35.7 & & -266.7 & & 164.6 & & 141.8 & \\
\hline Lower_Secondary & & 4.8 & & -329.3 & & -1.0 & & 211.1 & \\
\hline Upper_Secondary & & 158.7 & & -155.2 & & 1673.1 & & 126.4 & \\
\hline Higher Education & Education & 210.0 & 409.2 & -2.3 & -753.5 & . & 1836.7 & . & 479.3 \\
\hline Land & & -447.7 & & 123.8 & & -4509.5 & & -99.9 & \\
\hline Land2 & Land & 99.9 & -347.8 & -31.2 & 92.6 & 1071.8 & -3437.7 & 26.2 & -73.7 \\
\hline Coastal & & - & & - & & -364.8 & & 6.5 & \\
\hline InlandDelta & & - & & - & & -1592.0 & & 14.9 & \\
\hline Low Mountains & & - & & - & & 628.6 & & -19.3 & \\
\hline High Mountains & Region & - & - & - & - & 685.2 & -643.1 & -312.3 & -310.3 \\
\hline Buddhist & & - & & - & & 1156.9 & & 15.0 & \\
\hline Catholic & Religion & - & - & - & - & 44.4 & 1201.3 & 8.2 & 23.2 \\
\hline & & & 100 & & 100 & & 100 & & 100 \\
\hline
\end{tabular}




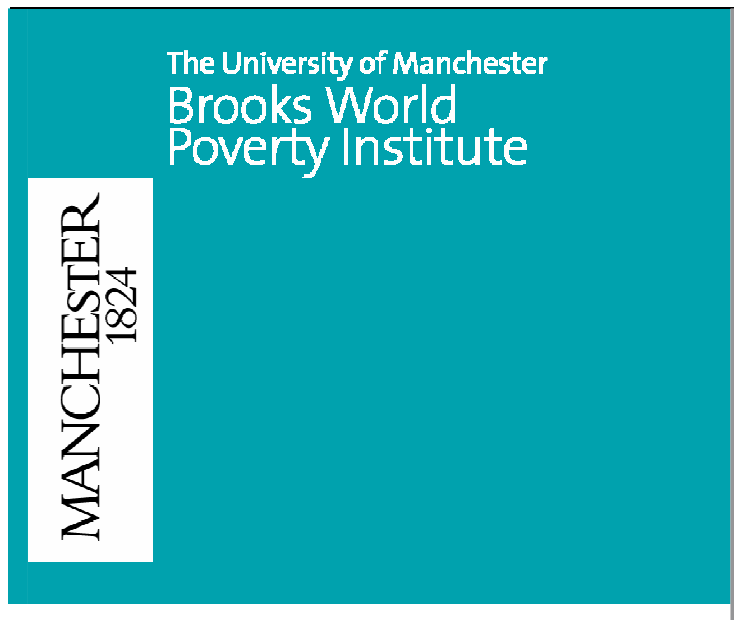

Executive Director

Professor Tony Addison

Research Director

Professor Michael Woolcock

\section{Associate Director}

Professor David Hulme

\section{Contact:}

Brooks World Poverty Institute

The University of Manchester

Humanities Bridgeford Street Building

Oxford Road

Manchester

M13 9PL

United Kingdom

\section{Email: bwpi@manchester.ac.uk}

www.manchester.ac.uk/bwpi
The Brooks World Poverty Institute (BWPI) creates and shares knowledge to help end global poverty.

BWPI is multidisciplinary, researching poverty in both the rich and poor worlds.

Our aim is to better understand why people are poor, what keeps them trapped in poverty and how they can be helped - drawing upon the very best international practice in research and policy making.

The Brooks World Poverty Institute is chaired by Nobel Laureate, Professor Joseph E. Stiglitz. 